\title{
Back to the tubule: microtubule dynamics in Parkinson's disease
}

\author{
Laura Pellegrini $^{1,2} \cdot$ Andrea Wetzel $^{1} \cdot$ Simone Grannó $^{1,3} \cdot$ George Heaton $^{1} \cdot$ Kirsten Harvey $^{1}(\mathbb{D}$
}

Received: 22 May 2016/Revised: 18 August 2016/Accepted: 29 August 2016/Published online: 6 September 2016

(C) The Author(s) 2016. This article is published with open access at Springerlink.com

\begin{abstract}
Cytoskeletal homeostasis is essential for the development, survival and maintenance of an efficient nervous system. Microtubules are highly dynamic polymers important for neuronal growth, morphology, migration and polarity. In cooperation with several classes of binding proteins, microtubules regulate long-distance intracellular cargo trafficking along axons and dendrites. The importance of a delicate interplay between cytoskeletal components is reflected in several human neurodegenerative disorders linked to abnormal microtubule dynamics, including Parkinson's disease (PD). Mounting evidence now suggests PD pathogenesis might be underlined by early cytoskeletal dysfunction. Advances in genetics have identified PD-associated mutations and variants in genes encoding various proteins affecting microtubule function including the microtubule-associated protein tau. In this review, we highlight the role of microtubules, their major posttranslational modifications and microtubule associated proteins in neuronal function. We then present key evidence on the contribution of microtubule dysfunction to PD. Finally, we discuss how regulation of microtubule
\end{abstract}

Laura Pellegrini and Andrea Wetzel are joint first authors.

Kirsten Harvey

kirsten.harvey@ucl.ac.uk

1 Department of Pharmacology, UCL School of Pharmacy, University College London, 29-39 Brunswick Square, London WC1N 1AX, UK

2 Laboratory of Neurogenetics, National Institute on Aging, National Institutes of Health, 35 Convent Drive, Bethesda, MD 20982-3707, USA

3 Department of Neurodegenerative Disease, UCL Institute of Neurology, University College London, Queen Square, London, UK dynamics with microtubule-targeting agents and deacetylase inhibitors represents a promising strategy for innovative therapeutic development.

Keywords Parkinson's disease - Cytoskeleton .

Microtubule dynamics - Axonal transport - Tau .

PARK genes · LRRK2 - Wnt signalling ·

Microtubule targeting agents

\section{Introduction}

PD is a neurodegenerative disorder characterised by significant degeneration of dopaminergic neurons within the substantia nigra pars compacta of the midbrain [1,2]. It is the second most common neurodegenerative disease, with a general prevalence of $0.3 \%$ in industrialised countries [3]. PD aetiology is complex and still poorly understood. Environmental exposure and genetic predisposition contribute to the incidence of the disease, but ageing remains the major risk factor. The prevalence increases from $1 \%$, in people over 60 years of age, to $4-5 \%$ in individuals over 80 years of age [3, 4]. Most commonly, patients develop late-onset PD between the age of 60 and 70, but some cases are diagnosed before the age of 50, classified as early onset PD [5]. A number of studies suggest also higher prevalence amongst men than women, although these findings remain controversial [3]. Around $90 \%$ of PD cases are sporadic, but the continuing discovery of several causative mutations linked to familial forms of PD may also improve understanding of the pathogenesis in sporadic cases [3, 6, 7]. Over the last 20 years, genome-wide association studies and genetic analysis identified numerous loci containing causative mutations and PD risk 
variants. Some of these mutations are causative for PD, others for clinically similar parkinsonian syndromes [8].

The cardinal parkinsonian symptoms of progressive bradykinesia, rigidity and resting tremor have long been described [9]. Though PD is regarded as foremost a movement disorder, there are a number of well-described non-motor symptoms, such as autonomic dysfunction, sleep disturbance, depression, cognitive decline and dementia [10]. Moreover, a variety of molecular and cellular pathways have been suggested to play a role in the pathogenesis of PD. These include, but are not limited to, accumulation of misfolded protein aggregates associated with proteasomal and autophagic dysfunction, neuroinflammation, mitochondrial damage and oxidative stress [11-14]. Development of effective interventional therapies currently poses a major challenge partially due to the diversity of affected molecular pathways and lack of consensus on which mechanisms might constitute the primary insult leading to PD. Currently, dopaminergic transmission is partially restored in a majority of newly diagnosed patients by administration of the neurotransmitter precursor levodopa [15]. Although there are temporary improvements in symptoms, the levodopa therapy tends to lose efficacy over time and often leads to debilitating side effects [15-17]. Long-term studies have shown that early co-administration of bromocriptine may delay the onset of side effects [18, 19]. Despite having produced significant improvements in PD patients, particularly at early stages, levodopa therapy remains a non-disease-modifying approach.

Mounting evidence suggests that deregulation of neuronal cytoskeleton function constitutes a key insult during the pathogenesis of neurodegenerative diseases. Understanding the fine regulation of cytoskeletal components particularly important for microtubule dynamics, axonal transport and synaptic function is a crucial first step to unravel dysfunctional mechanisms leading to neurodegeneration. Microtubules form intracellular transport highways, which allow trafficking of molecular cargo along axons to facilitate neuronal function. Dynamic reorganisation of microtubules has long been known to mediate essential aspects of cellular homeostasis, including mitosis, vesicular transport, organelle and protein trafficking as well as maintenance of structural integrity. Microtubule dysfunction is increasingly viewed as important contributor to $\mathrm{PD}$ pathogenesis. Lewy bodies, a classical histological feature of PD, have been found to contain tubulin and neurofilaments, key elements of the neuronal cytoskeleton [20-22]. Moreover, multiple lines of evidence suggest that the PDassociated proteins $\alpha$-synuclein, parkin, PINK1 and the Leucine-rich repeat kinase 2 (LRRK2) may modify microtubule stability [23-26]. Here, we outline the role of microtubules within neuronal function, their posttranslational modifications and associated proteins. We further explore the evidence linking microtubule dysfunction to PD, before discussing recent advances in the possible use of microtubule targeting therapeutics for neurodegenerative diseases.

\section{Microtubules}

\section{Structural overview}

Microtubules are highly dynamic intracellular polymers. In close association with F-actin, they form an integral component of the neuronal cytoskeleton [27]. As well as controlling neuronal morphology, the cytoskeleton also regulates trafficking and cell division [28]. Microtubules are assembled modularly from $\alpha / \beta$-tubulin heterodimers, of which six and seven isoforms are currently described, respectively [27, 29]. This composition generates polarity in microtubules, with growth and shrinkage occurring at the plus end [27, 30], although minus end polymerisation has also been observed [28]. At the core of this process is a tight balance of growth and shrinkage referred to as dynamic instability (Fig. 1a) [31, 32].

Primary assembly of GTP-bound $\alpha / \beta$-tubulin heterodimers generates linear protofilaments bound to a template structure known as the $\gamma$-tubulin ring complex [33, 34]. The $\gamma$-tubulin complex caps the microtubule minus end resulting in microtubule growth from the plus end. The intradimeric, $\alpha$-tubulin-bound GTP occupies the 'non-exchangeable' site (N-site), and exerts a fixed structural role $[35,36]$. Heterodimers are bound to the growing plus end via $\alpha$-tubulin interaction with an interdimeric GTP molecule, bound to $\beta$-tubulin at the 'exchangeable' site (E-site) (Fig. 1b) [27, 36]. The GTP cap must remain at the foremost plus end for efficient assembly, and is therefore hydrolysed to GDP upon binding of a new GTP-bound heterodimer, effectively shifting upwards in position. Protofilaments then laterally assemble into a circular array with 13-fold symmetry, resulting in a tubular structure approximately 15-25 $\mathrm{nm}$ in diameter (Fig. 1a). Hydrolysis of the E-site GTP cap results in a longitudinal strain along the microtubule, facilitating disassembly of the protofilaments and release of free $\alpha / \beta$-tubulin heterodimers $[36,37]$. Although the exact structural nature of this process has long remained elusive, it has recently been shown that loss of the E-site GTP leads to compression of the interdimeric interface, with resultant instability [36]. The GTP-dependence inherent to tubulin polymerisation is primarily responsible for its dynamic nature. Self-nucleation of microtubules in the presence of GTP is observable in vitro [38], although multiple accessory proteins facilitate 


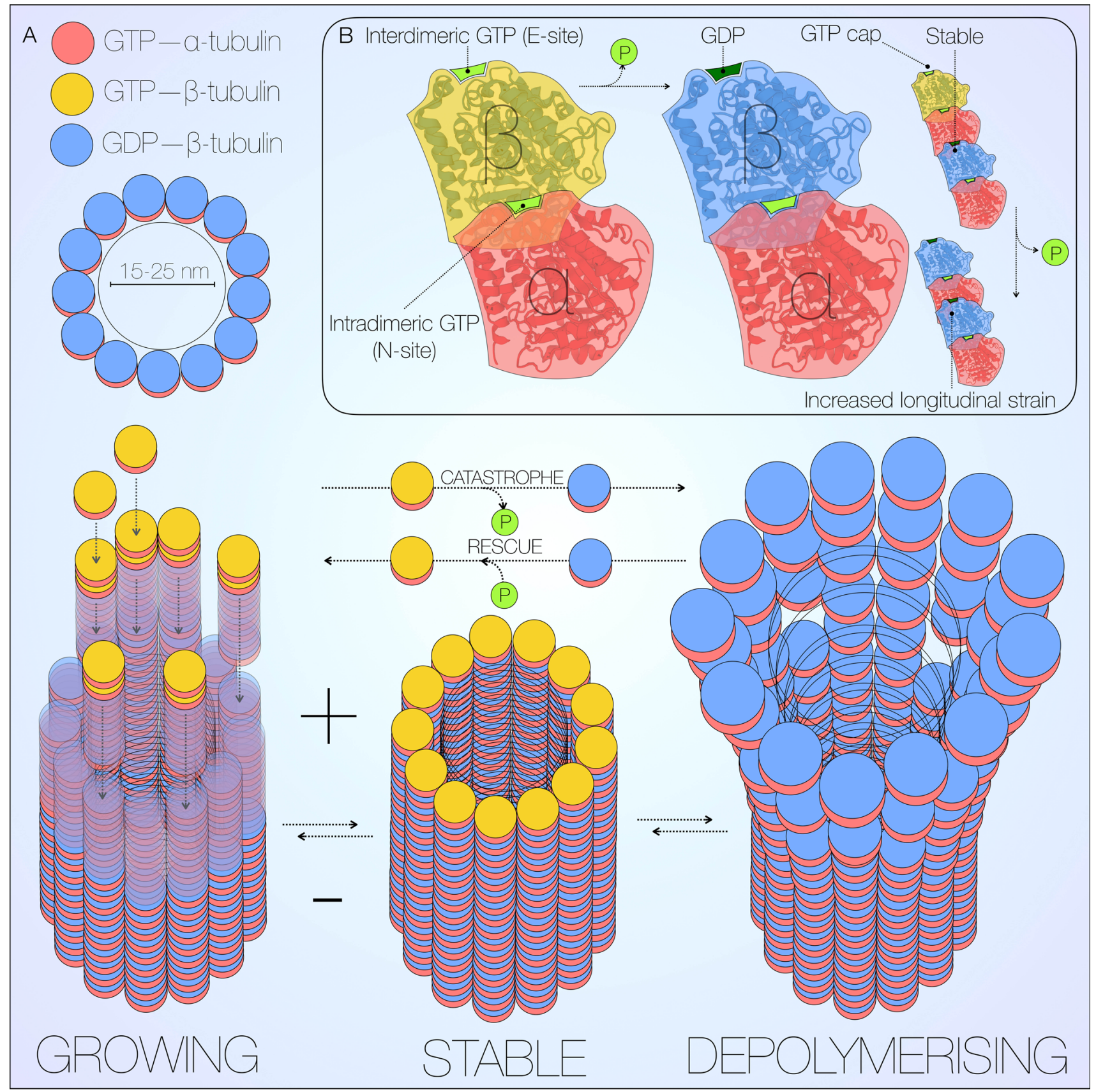

Fig. 1 Microtubule structure and dynamic instability. Microtubules are long, dynamic, cylindrical polymers with a diameter of $15-25 \mathrm{~nm}$. Each microtubule is composed by 13 protofilaments of $\alpha / \beta$-tubulin heterodimers, which assemble forming a tubular structure (a). At microtubule plus ends, GTP-bound $\beta$-tubulin caps growing filaments, attracting further GTP-bound $\alpha / \beta$-tubulin heterodimers. Upon binding of a new heterodimer, $\beta$-tubulin GTP on the filament undergoes hydrolysis at the 'exchangeable' site (E-site), ensuring the GTP cap

this highly energy dependent process intracellularly $[28,29,39]$.

In neurons, microtubules, actin filaments and neurofilaments compose the cytoskeleton, maintaining cell polarity, architecture and morphology [40]. Microtubule bundles are remains on the first heterodimer (b) [27, 36]. The cyclic incorporation and loss of GTP $\beta$-tubulin, stochastically alternates growing (rescue) stable and depolymerising states (catastrophe). The 'non-exchangeable' site ( $\mathrm{N}$-site) is occupied by the intradimeric, $\alpha$-tubulin-bound GTP, and ensures structural stability [35, 36]. Crystal structure of tubulin from PDB [http://www.rcsb.org/pdb/pv/pv.do?pdbid= 1TUB\&bionumber=1], mechanism adapted from [36]

spread throughout the soma, dendrites and axon, connecting these different compartments [30]. The axonal shaft displays uniform plus end orientation, while dendrites possess more variable combinations [27, 30]. Microtubules also have a prominent role in growth cone function, a 
highly dynamic process directing axonal growth during neuronal development (Fig. 2). The complex process of axon outgrowth requires spontaneous electrical activity provided by calcium and sodium channels [41-43] as well as a set of specific growth cone receptors interpreting external guidance cues [44]. Activation of growth cone receptors triggers intracellular signalling pathways leading to the formation of a 'molecular clutch' [45]. This complex links receptors to the F-actin cytoskeleton present in the periphery of growth cones [45, 46]. Here, dynamic microtubules are tethered to F-actin filaments through a variety of cross-linking proteins [27, 47]. Examples include the plus-tip interacting protein (+TIP) class, which mediate axonal extension both in Drosophila and mouse cortical neurons through the subfamily of spectraplakins [48, 49]. The centre of growth cones is composed of stable microtubule bundles, which are surrounded by a dynamic F-actin network [50]. The cytoskeletal composition within growth cones determines their shape and movement during development. F-actin filaments exert pressure on the plasma membrane via a 'treadmilling' mechanism of directional assembly and disassembly [27, 44]. At the same time, microtubules are guided and effectively pulled along the direction of F-actin polymerisation, both outwardly and

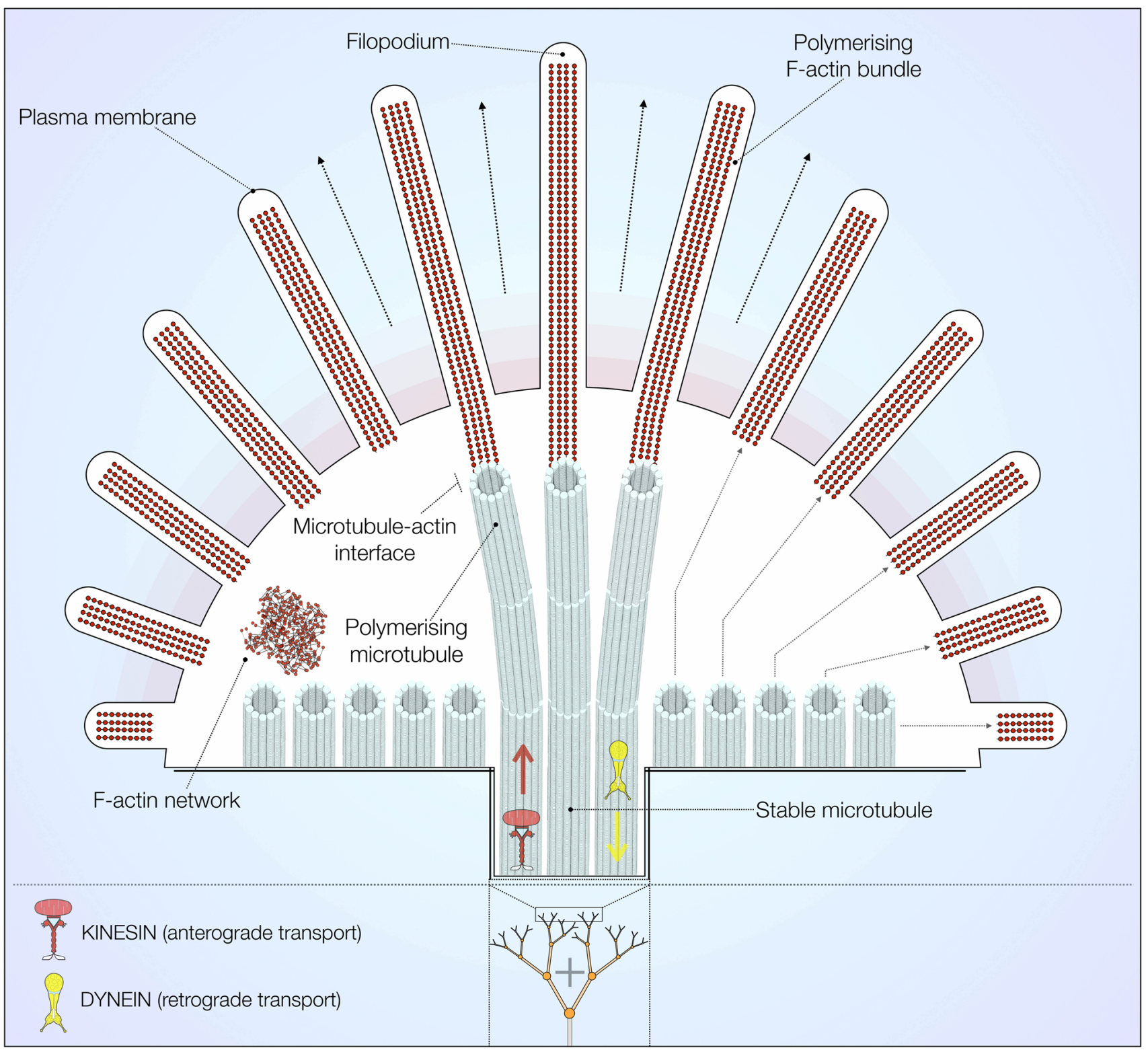

Fig. 2 Cytoskeletal distribution in growth cones. At the growth cone, F-actin extends the plasma membrane forming filopodia and polymerises in bundles. These F-actin bundles associate with dynamic and growing microtubules to promote axon outgrowth. Stable microtubule bundles are present in the centre of growth cones 
in retrograde flow [44]. The combination of these processes results in remodelling and/or extension of the neuronal plasma membrane [51, 52]. The importance of axonal outgrowth and growth function for late-onset neurodegenerative diseases is currently unclear but it should be noted that changes in neurite outgrowth and growth cone morphology in genetic PD models have been observed, for example, in LRRK2 PD models [23, 53-55].

\section{Post-translational modifications of microtubules}

Microtubule dynamics and therefore stability are primarily regulated through a number of post-translational modifications (PTMs) of tubulin, both in its heterodimeric and protofilament conformation (Fig. 3). Multiple modifications often occur simultaneously and vary depending on cell type and subcellular localisation. Such complexity results in the generation of microtubules with spatially and temporally dependent characteristics. PTMs also regulate microtubule binding to a high number of proteins, further contributing to tight regulation of neuronal cytoskeletal dynamics. Here, we focus on current evidence surrounding some of the welldescribed PTMs which have been observed to play a role in microtubule function: tyrosination, polyglutamylation, acetylation as well as generation of $\Delta 2$-tubulin (Fig. 3) [29]. We would like to stress that the significance of the findings discussed below for physiological and pathogenic events remains controversial in nature.

In 1975, Arce et al. identified tyrosination as the first PTM of tubulin [56], characterising the incorporation of

\begin{tabular}{|c|c|c|c|c|c|}
\hline Acetyl & & $\begin{array}{l}a \\
\beta \\
\frac{a}{\beta} \\
a \\
\beta\end{array}$ & 2 & dase & $\begin{array}{l}\text { utamylation } \\
\text { Tyrosination/ } \\
\text { detyrosination }\end{array}$ \\
\hline PTM & SITE & ENZYME & OPPOSING ENZYME & FUNCTION & REFERENCE \\
\hline $\begin{array}{l}\text { Tyrosination/ } \\
\text { Detyrosination }\end{array}$ & $\begin{array}{l}a-\beta \\
\text { heterodimers }\end{array}$ & $\begin{array}{l}\text { Tubulin tyrosine } \\
\text { ligase (TTL) }\end{array}$ & $\begin{array}{l}\text { Unidentified } \\
\text { carboxy-peptidase }\end{array}$ & $\begin{array}{l}\text { - Organisation of } \\
\text { neuronal circuitry. } \\
\text { - Myosin, actin and MT } \\
\text { filament localisation. } \\
\text { - Recruitment of motor } \\
\text { and CLIP proteins. }\end{array}$ & $\begin{array}{l}{[56,57,59} \\
63,64,67 \\
73]\end{array}$ \\
\hline $\begin{array}{l}\text { Acetylation/ } \\
\text { Deacetylation }\end{array}$ & a lysine -40 & aTAT1, NatA & HDAC6, SIRT2 & $\begin{array}{l}\text { - Local protein-protein } \\
\text { interactions } \\
\text { - Trafficking and } \\
\text { recruitment of motor } \\
\text { proteins. } \\
\text { - Axonal growth and } \\
\text { neuronal plasticity. }\end{array}$ & $\begin{array}{l}{[89,91,92,} \\
99,101,102]\end{array}$ \\
\hline Polyglutamylation & $\begin{array}{l}a-\beta \\
\text { heterodimers }\end{array}$ & Polyglutamylase & Deglutamylase & $\begin{array}{l}\text { - Modification of MAP } \\
\text { and motor protein } \\
\text { binding. }\end{array}$ & $\begin{array}{l}{[76-79,83} \\
85,86]\end{array}$ \\
\hline $\begin{array}{l}\triangle 2 \text {-tubulin } \\
\text { generation }\end{array}$ & $\begin{array}{l}a-\beta \\
\text { heterodimers }\end{array}$ & Deglutamylase & Polyglutamylase & $\begin{array}{l}\text { - Largely unknown, } \\
\text { increased stability? }\end{array}$ & {$[74,75]$} \\
\hline
\end{tabular}

Fig. 3 Post-translational modifications of tubulin. Overview of posttranslational modifications (PTMs) of tubulin including target sites, associated enzymes and known effects. Microtubules in subcellular compartments are functionally and structurally distinguished, with stable and dynamic axonal microtubules presenting differential PTM distributions 
tyrosine onto the $\alpha$-tubulin $\mathrm{C}$-terminal in rat brain homogenates [56]. The reversibility of this reaction was described by Hallak et al. shortly after [57]. Interestingly, $\alpha$-tubulin is tyrosinated in its nascent state [58], with the cyclic addition and removal of C-terminal tyrosine (detyrosination) constituting its primary modification. The carboxypeptidase responsible for $\alpha$-tubulin detyrosination remains unidentified at present. Moreover, its tyrosinating counterpart tubulin tyrosine ligase (TTL) is far better characterised [59-62]. TTL acts exclusively on $\alpha / \beta$ heterodimers and is thought to tyrosinate all soluble tubulin prior to microtubule polymerisation. Thus, all assembling microtubules are solely composed of tyrosinated tubulin. This notion is strongly suggestive of correct microtubule assembly being dependent on tyrosination. In accordance, selective knockout of TTL expression has been shown to induce death in mice at 1 day of age [63]. TTL ablation resulted in widespread disturbance of neuronal organisation, with prominent disruption of cortico-thalamic circuitry acting as a likely candidate for lethality [63]. TTL-null cultured neurons also exhibit morphological abnormalities, including excessive neurite outgrowth with premature axon differentiation [63]. Similarly, Marcos et al. reported that TTL knockout in precerebellar neurons results in aberrant filopodia projections and enlarged growth cones, with significantly altered localisation of myosin and actin filaments as well as microtubules [64]. Unsurprisingly, these cellular areas are rich in tubulin polymerisation.

At the molecular level, tubulin lacking a C-terminal tyrosine functional group exhibits a greater capacity for recruitment of motor proteins over its tyrosinated counterparts. Kinesins, a class of molecular motors responsible for trafficking along microtubules, have been reported to bind the exposed glutamate subunit of detyrosinated microtubules with 2.8 -fold higher binding affinity relative to tyrosinated microtubules [65]. Immunofluorescence imaging of modified kinesin heavy chain (KIF5C) has shown that kinesin-1 preferentially binds and traffics along detyrosinated microtubules in neuronal cell lines [66]. In 2009, Konishi and Setou proposed that the relative abundance of detyrosinated in comparison to tyrosinated tubulin in neurons may act as a candidate mechanism for directing kinesin-1 to specific neuronal cellular compartments. Kinesin-1 is typically confined to axonal regions of neurons. Konishi et al. reported that inhibition of TTL via siRNA knockdown in rat hippocampal neurons resulted in a decrease in tubulin tyrosination, and a subsequently broader distribution of microtubule-associated kinesin-1 to both axonal and dendritic cellular compartments [67].

Microtubules with long turnover times appear enriched with detyrosinated tubulin, associating detyrosination with increased microtubule stability [68]. Intriguingly, whilst detyrosination might be necessary for increased stability, it does not appear to be a sufficient condition [69, 70]. +TIPs have also been shown to differentially bind to detyrosinated microtubules. In mammalian fibroblasts, cytoplasmic linker protein (CLIP) 170 shows higher affinity for tyrosinated microtubules, whereas detyrosination of $\alpha$ tubulin inhibits CLIP170 binding [71, 72]. These findings are strongly suggestive of tyrosination as a key mechanism mediating microtubule protein-protein interactions. More recent evidence suggests that detyrosinated microtubules may play a modulatory role in striated muscle mechanotransduction [73]. Moreover, detyrosinated tubulin may upregulate X-ROS signalling, a transduction pathway through which reactive oxygen species (ROS) are produced in response to mechanical stress. In Duchenne muscular dystrophy (DMD), a rare X-linked condition, alterations to microtubule dynamics lead to detrimental enhancement of X-ROS signalling with downstream disruption of calcium signalling. Kerr et al. demonstrate that in vivo inhibition of detyrosination through TTL overexpression reduces stress induced X-ROS and calcium signalling in a DMD mouse model [73].

Detyrosination of $\alpha$-tubulin exposes the C-terminal glutamate which is further removed by the enzyme deglutamylase. Deglutamylation subsequently generates the $\Delta 2$-tubulin isoform. Removal of the TTL binding, C-terminal glutamate residue renders this tubulin isoform resistant to tyrosination. In contrast to detyrosination, this PTM is irreversible. Despite $\Delta 2$-tubulin representing $\sim 35 \%$ of total brain tubulin, its functional role remains largely unclear [74]. An early characterisation study localised $\Delta 2$-tubulin to early differentiating neurons and growth cones [75]. $\Delta 2$-tubulin is also largely confined to highly stable structures such as centrosomes and primary cilia. Similar to tyrosination, however, removal of C-terminal glutamate might simply correlate with enhanced microtubule stability [75].

First described in 1990, polyglutamination is a major PTM capable of generating further diversity in tubulin [76]. Employing a combination of HPLC and mass spectrometry on mammalian brain, Eddé et al. observed the addition of glutamate residues close to the $\mathrm{C}$-terminal end of $\alpha$-tubulin [76]. Shortly thereafter, several groups demonstrated independently that this modification also occurs on $\beta$ tubulin [77-79]. Glutamination of both $\alpha$ and $\beta$ tubulin occurs over two phases. First, 'initiation' reaction catalyses the formation of a covalent bond conjoining the $\gamma$-carboxyl group of the modified glutamate and the amine group of the added glutamate residue. Glutamate residues are subsequently incorporated as part of a secondary 'elongation' reaction to form acidic side chains of varying length [80]. Polyglutamylases, driving polyglutamination, are large proteins containing TTL-like (TTLL1) catalytic subunits 
[81]. Polyglutamylase subunit 1 (PGs1) has been identified through immunoprecipitation assays with mouse brain tubulin [82]. Although PGs1 is not directly linked to enzymatic activity, it is significantly enriched in hotspots of polyglutaminated microtubules-namely mitotic spindle, neuronal microtubule, axonomes and centrioles [80, 83, 84]. As such, PGs1 has been suggested as adaptor for recruitment of a larger polyglutamylase complex. The ROSA22 mouse, which exhibits loss of functional PGs1 activity, may offer indirect insight into the role of polyglutamylated microtubule [83, 84]. These mice display significantly reduced microtubule polyglutamylation in neurons alongside abnormal sperm flagella, heightened intermale aggressive behaviour and a reduction in body fat content [84]. Subsequent in-depth analysis of ROSA22 mutants revealed decreased binding of $\alpha$-tubulin with several MAP and kinesin-3 motor proteins, although kinesin-1 and kinesin-2 binding appeared unaltered [83]. Similar to other tubulin PTMs, it is likely that polyglutamination impacts trafficking and microtubule dynamics through differential recruitment of molecular motor proteins and MAPs $[85,86]$.

Acetylation has long been considered to be specific to $\alpha$ tubulin, occurring on the luminal surface of microtubule protofilaments at the lysine 40 residue [87]. More recently, however, Chu et al. identified the lysine 252 residue of $\beta$ tubulin as a novel acetylation site. This PTM is catalysed by the acetyltransferase San at the polymerisation interface [88]. At present, however, evidence remains limited as to the functional significance of $\beta$-tubulin acetylation. Interestingly, cryo-electron microscopy analysis of protofilament distribution indicates that $\alpha$-tubulin acetylation does not appear to alter microtubule architecture or $\alpha$ tubulin confirmation significantly. Howes et al. suggest instead that acetylation might regulate luminal proteinprotein interactions within microtubules [89]. Deacetylase and acetyltransferase enzymes are considered to be responsible for tight regulation of $\alpha$-tubulin de-/acetylation, respectively. In 2002, Hubbert et al. first identified histone deacetylase class II (HDAC6) as an $\alpha$-tubulin deacetylase [90]. The authors observed in vivo $\alpha$-tubulin deacetylation following HDAC6 overexpression [90]. Conversely, siRNA-mediated HDAC6 knockdown enhances lysine 40 acetylation [90]. These findings were further corroborated by Zhang et al., who reported a direct interaction between HDAC6 and $\beta$-tubulin in a yeast-two hybrid assay. HDAC6 mediated $\alpha$-tubulin deacetylation was also observed in mouse embryonic stem cells within the same study [91]. It is important to point out that histone deacetylases are not tubulin-specific enzymes. They additionally target chromatin with modulatory effects on chromosomal function. This notion should be considered when assessing off-target effects of pharmacological agents affecting deacetylation.
Sirtuin 2 (SIRT2), an additional tubulin deacetylase has been shown to interact with soluble heterodimers as well as assembled microtubules [92]. Interestingly, the oxidative neurotoxin 6-hydroxydopamine (6OHDA) was shown to influence SIRT2 activity and microtubule dynamics through more than one mechanism, leading to impaired nuclear import of certain transcription factors [93, 94]. Consistently, altered subcellular localisation of transcription factors has been reported in post-mortem PD brains $[93,95,96]$.

Acetyltransferase activity, responsible for $\alpha$-tubulin acetylation, was first described in Chlamydomonas flagellar [97]. In mammalian cells, acetylation is reportedly catalysed by $\alpha$-tubulin acetyltransferase 1 ( $\alpha$ TAT1) or by $n$ - $\alpha$-acetyltransferase A (NatA) [98]. Despite the available evidence, the exact mechanism by which acetyltransferases and deacetylases gain access to lysine 40 is not fully understood. Nogales et al. suggested slow diffusion of acetyltransferase down the lumen of assembled microtubules as a candidate mechanism [87]. An alternative model proposes that variability in lateral protofilament interactions may result in transient, localised openings of the microtubule wall. This model has been likened to a 'breathing' mechanism following cryo-electron microscopy observation of small structural defects in microtubule walls $[99,100]$.

Akin to tyrosination, acetylation has been implicated in control of cellular trafficking, with particular relevance to recruitment and activity of motor proteins [90, 101]. Reed et al. reported that loss of $\alpha$-tubulin acetylation modifies kinesin-1 binding and trafficking activity in vitro [102]. Increased $\alpha$-tubulin acetylation is also observed during axogenesis, suggesting its potential role in axonal growth and neuronal plasticity [101].

\section{Microtubule-mediated axonal transport}

Microtubules form intracellular highways along which organelles, vesicles and proteins are constantly trafficked. The unique architecture of neurons, set apart by their long axons and dendrites, has posed the evolutionary need for a tightly organised microtubule network able to ensure efficient long-range transport. Unsurprisingly, altered microtubule regulation was shown to be an early event in neurodegenerative diseases associated with axonal transport defects [103-108].

Axonal transport is chiefly described as the active movement of subcellular structures along neuronal microtubules (Fig. 4) [109, 110]. In a 1948 seminal study, Weiss and Hiscoe first demonstrated its existence in chicken sciatic nerves [111]. Correct sorting of cargos and organelles requires tight regulation of this cellular mechanism at multiple levels [112]. Axonal transport is classified into 


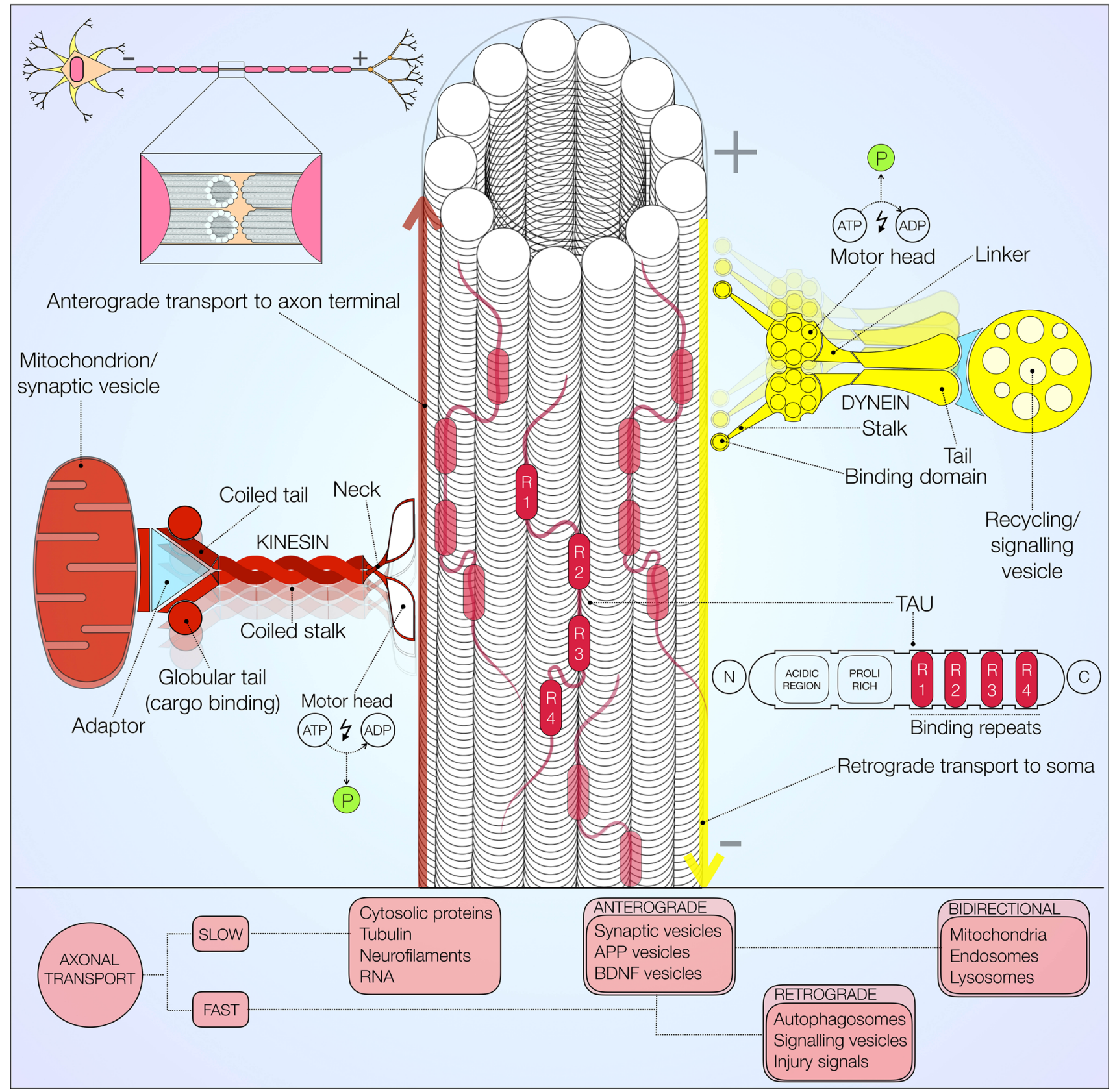

Fig. 4 Microtubule-mediated axonal transport. Axonal microtubules are specialised in transmitting vesicles and other cargo via molecular motors. Microtubule organisation and modulation by MAPs (such as tau) also aids transport. Kinesin (left red) performs anterograde transport to axonal terminals. Dynein (right yellow) moves

fast and slow, according to cargo speed. Furthermore, directionality of movement away from, or towards the soma is used to distinguish anterograde from retrograde axonal transport, respectively [113]. ATP dependent motor proteins and a multitude of kinases regulate this complex process. Kinesins, first purified in 1985 from the squid axoplasm, are a large family of motor proteins essentially involved in anterograde transport [114]. Structurally, retrogradely towards the cell body. Fast and slow axonal transports drive organelles, vesicles and proteins along the axon. A tight balance of anterograde, bidirectional and retrograde transport is required to avoid either accumulation or depletion of cellular components [40]

kinesins are cytosolic proteins with two globular heads, binding ATP and microtubules, connected to a cargo binding tail domain (Fig. 4, left). The remarkable binding specificity of kinesins arises from an extremely diverse population of tail domain binding motifs. The 'stepwise' movement of kinesins along microtubules is an energy dependent process requiring ATP hydrolysis [115]. Dynamic association and dissociation of these molecular 
motors is also dependent on local microtubule concentration, the presence of kinases and adaptor proteins $[113,116]$.

Anterograde transport is associated with axonal growth and synaptic vesicle replenishment [117]. Synaptic vesicles, dense core vesicles, brain-derived neurotrophic factor (BDNF) containing vesicles and amyloid precursor protein (APP) exemplify the heterogeneity of cargo actively trafficked along the axon via anterograde transport [40]. The kinesin-3 family, particularly the motor proteins KIF1A and KIF1B, is known to be involved in this transport modality [118]. Fast anterograde transport is responsible for movement of vesicles emerging from the Golgi, at an average speed of 200-400 mm per day [40]. Administration of transport blocking antimitotic agents, namely colchicine and vinblastine, has been employed to demonstrate the essential role of microtubules in axonal transport [119]. By contrast, cytosolic proteins and cytoskeletal polymers such as neurofilaments and tubulin itself are shuttled at much slower speeds of 0.1-3 mm per day [113].

Retrograde transport, primarily mediated by cytoplasmic dyneins (Fig. 4, right), is associated with intracellular recycling and injury signalling [120]. Dynein is composed of two heavy chains, intermediate, light intermediate and light chains [40]. Large microtubule binding protein complexes (MBPs) such as dynactin are responsible for tethering cargo to dyneins. Additionally, an array of adaptor proteins, of which lissencephaly-1 and huntingtin are prime examples, contributes to this process [113]. A number of +TIPs and end binding proteins, such as EB1 and EB2, are recruited to the highly dynamic microtubule plus ends thus facilitating active loading of dynein-cargo complexes [121]. Signalling endosomes, autophagosomes and injury signalling molecules are transported retrogradely towards the cell soma [120]. Microtubule instability and impaired axonal transport have been suggested to cause incomplete fusion of autophagosomes with lysosomes leading to autophagic vesicle accumulation [122]. Arduino and others also reported defects in autophagic vesicle mobilisation towards lysosomes due to disruption of microtubule dependent trafficking [123]. Overall, axonal transport regulates the functional distribution of several proteins through remarkably diverse cargo binding specificity. This notion also implies that a large variety of disease-associated proteins are likely to interact with microtubules.

\section{The role of tau in health and disease}

Mutations and variants in the MAPT gene, encoding the microtubule-associated protein tau, as well as deposition of misfolded tau as neuropathological correlate have been linked to several neurodegenerative diseases, such as familial frontotemporal dementia with parkinsonism linked to chromosome 17 [124], progressive supranuclear palsy [125], chronic traumatic encephalopathy [126], amyotrophic lateral sclerosis (ALS) [127], Alzheimer's disease (AD) and PD [121-123, 128, 129].

Microtubule dynamics are heavily dependent on an array of microtubule-associated proteins (MAPs) selectively and transiently decorating axonal microtubules. Both microtubule orientation and MAP subset are determinants of transport directionality and organelle sorting. Accordingly, axons and dendrites differ by their MAP subset. An important example is the differential distribution of two well-described MAPs: MAP2 and tau. While MAP2 is predominant in dendritic microtubules, tau is relatively more abundant in axons [30].

Tau is encoded by the MAPT gene located on chromosome 17q21 [130]. It associates with axonal microtubules to promote stability, although unbound tau is also found in the cytosol [131, 132]. In the human brain, tau isoforms ranging from 352 to 441 amino acids are generated through alternative splicing [131].

Tau protein structure can be divided into a highly acidic $\mathrm{N}$-terminal projection domain, a central proline-rich region and a C-terminal domain. The $\mathrm{N}$-terminus interacts with other cytoskeletal elements and the plasma membrane. The C-terminus usually contains three to four highly homologous 31-32 amino acid repeats functioning as binding domains [133]. Amongst these, the KXGS motif is critical for microtubule interaction as well as regulation of tau folding and aggregation. Furthermore, the tau $\mathrm{N}$-terminal projection domain has long been proposed to affect axonal microtubule spacing and diameter [134]. Recent high-resolution in vitro polymerisation studies, suggest that tau may also influence microtubule-actin network cross-linking [135]. It was further shown that tau promotes tubulin polymerisation and actin bundling in vitro [134, 136]. Microtubule assembly is heavily dependent on the tau phosphorylation state; given a dephosphorylated tau conformation is necessary for polymerisation [137]. Consequently, research efforts have focused on the identification of tau regulatory kinases and phosphatases influencing microtubule binding. Most described tau kinases are proline directed protein kinases including glycogen synthase kinase $3 \beta$ (GSK3 $\beta$ ), MAP kinase (MAPK), cdc2 and cdk5. Specifically, serine 262 and threonine 231 phosphorylation at the microtubule binding site significantly reduces microtubule binding resulting in filament disassembly [136, 138].

Perhaps expectedly, tau actively participates in axonal transport and neurite outgrowth [139, 140]. Through competition for microtubule binding sites with molecular motors, it may in fact prevent or reduce organelle and cargo trafficking [141]. PTMs of tau, reportedly 
phosphorylation and acetylation [142], exert a modulatory action on tau function, thus influencing microtubule stability. Mass spectrometry analysis identified a lysine-rich region in the microtubule binding site as a key acetylation site [142]. In the same study, both acetylation and phosphorylation appear to induce tau release from microtubules, in turn leading to an enriched pool of cytosolic tau prone to aggregation. In addition, loss of tau acetylation, an event enhancing tau phosphorylation, has been observed in $\mathrm{AD}$ patients and a murine model of tauopathy [143]. Studies in transgenic models expressing mutant tau suggest that loss of tightly regulated phosphorylation state results in microtubule destabilisation and abnormal tau aggregation [144, 145]. Intracellular tau accumulation can generate inclusions termed paired helical filaments (PHF) further assembled in neurofibrillary tangles (NFT) in $\mathrm{AD}$ [146, 147]. In addition to AD, hyperphosphorylated tau aggregates are a classical feature in a number of neurodegenerative diseases [128, 132, 133, 148]. In the context of PD, Lewy bodies are well-known to contain tau and $\alpha$ synuclein, a notion suggestive of a pathological interaction between the two proteins [149]. Accordingly, a direct tau$\alpha$-synuclein interaction has previously been reported [150]. In addition, protein kinase A and GSK3 $\beta$ have been proposed as kinases mediating $\alpha$-synuclein-dependent tau phosphorylation [151, 152]. This process may result in microtubule depolymerisation and reduced axonal transport.

Mutations in MAPT have been described in frontotemporal dementia (FTD) with Parkinsonism and progressive supranuclear palsy $[153,154]$. The importance of tau in neurodegeneration was further supported by genome-wide association studies identifying $M A P T$ as risk factor for sporadic PD [154, 155]. In addition, the H1 MAPT haplotype is significantly associated with increased susceptibility to PD $[153,155]$.

\section{Microtubule dysfunction in Parkinson's disease}

A growing body of evidence suggests abnormal neuronal cytoskeleton assembly and function as key processes in neurodegenerative disease. Several proteins linked to neurodegenerative diseases including PD have been reported to bind tubulin directly and/or modulate microtubule stability (Fig. 5) [23-25, 156]. Here, we focus on evidence surrounding a number of key microtubule-interacting proteins-parkin, PTEN induced putative kinase 1 (PINK1), leucine-rich repeat kinase 2 (LRRK2) and $\alpha$ synuclein (SNCA). Mutations in all corresponding genes cause autosomal forms of Parkinsonism [157]. Figure 5 summarises the major effects of PD-linked proteins on microtubules.
The parkin gene encodes a member of the E3 ubiquitin ligase family, which targets proteins for proteasomal degradation [158]. Exonic deletions in parkin were first identified in association to early onset autosomal recessive Parkinsonism in three unrelated Japanese families [159].

Physiological tubulin folding is dependent on the activity of multiple chaperone proteins. Dysfunctional protein folding machinery can induce toxic accumulation of misfolded tubulin heterodimers. Ren et al. reported that parkin enhances $\alpha / \beta$-tubulin ubiquitination and clearance via a direct interaction [156]. In the same study, PD-associated parkin loss of function mutations was shown to abolish tubulin ubiquitination. This observation is suggestive of a potential pathogenic mechanism, although further investigation is required to verify these findings. In a later study, the authors reported high affinity parkin-tubulin binding via the linker (partially corresponding to RING0), RING1 and RING2 domains [24]. These interactions were subsequently shown to partially rescue colchicine-induced microtubule depolymerisation. Perhaps surprisingly, the microtubule-stabilising properties of parkin appear not to be compromised by PD-linked mutations [24]. A more recent publication further characterised the structure of human parkin, comprising four domains: UDP (Unique Parkin Domain, also known as RING0), RING1, IBR (In Between Ring Domain) and RING2 (Fig. 5) [160]. The authors reported that the UDP domain co-interacts with RING1 and RING2, and contains a putative phosphopeptide binding site. PD-causing mutations were subsequently mapped to this site [160]. Parkin was further shown to decrease MAP kinase activity, reducing microtubule depolymerisation [161]. This mechanism may be neuroprotective to midbrain dopaminergic neurons, a cell population highly vulnerable to microtubule depolymerisation [162]. Interestingly, PD-linked parkin mutations appear to abolish this effect [161].

Parkin has also been reported to regulate mitochondrial trafficking for subsequent degradation (mitophagy) $[163,164]$. This mechanism is reportedly dependent on inhibitory phosphorylation of the mitochondrial Rho GTPase (Miro) [163, 165]. Miro, a calcium-binding GTPase, facilitates kinesin association with mitochondria, enabling their anterograde transport [166, 167]. Particularly, it is tethered to the mitochondrial surface via the adaptor protein milton. This interaction gives rise to a multi-protein complex binding kinesin heavy chain $[168,169]$. Its inhibition results in release of mitochondria from kinesin (Fig. 5, middle left) [163, 166]. Miro phosphorylation is chiefly mediated by the serine/threonine kinase PINK1. Parkin-directed mitochondrial degradation thus appears to be PINK1-dependent [163, 170-172]. Wang et al. proposed an elegant functional hypothesis to account for this mechanism: PINK1/parkin-mediated 


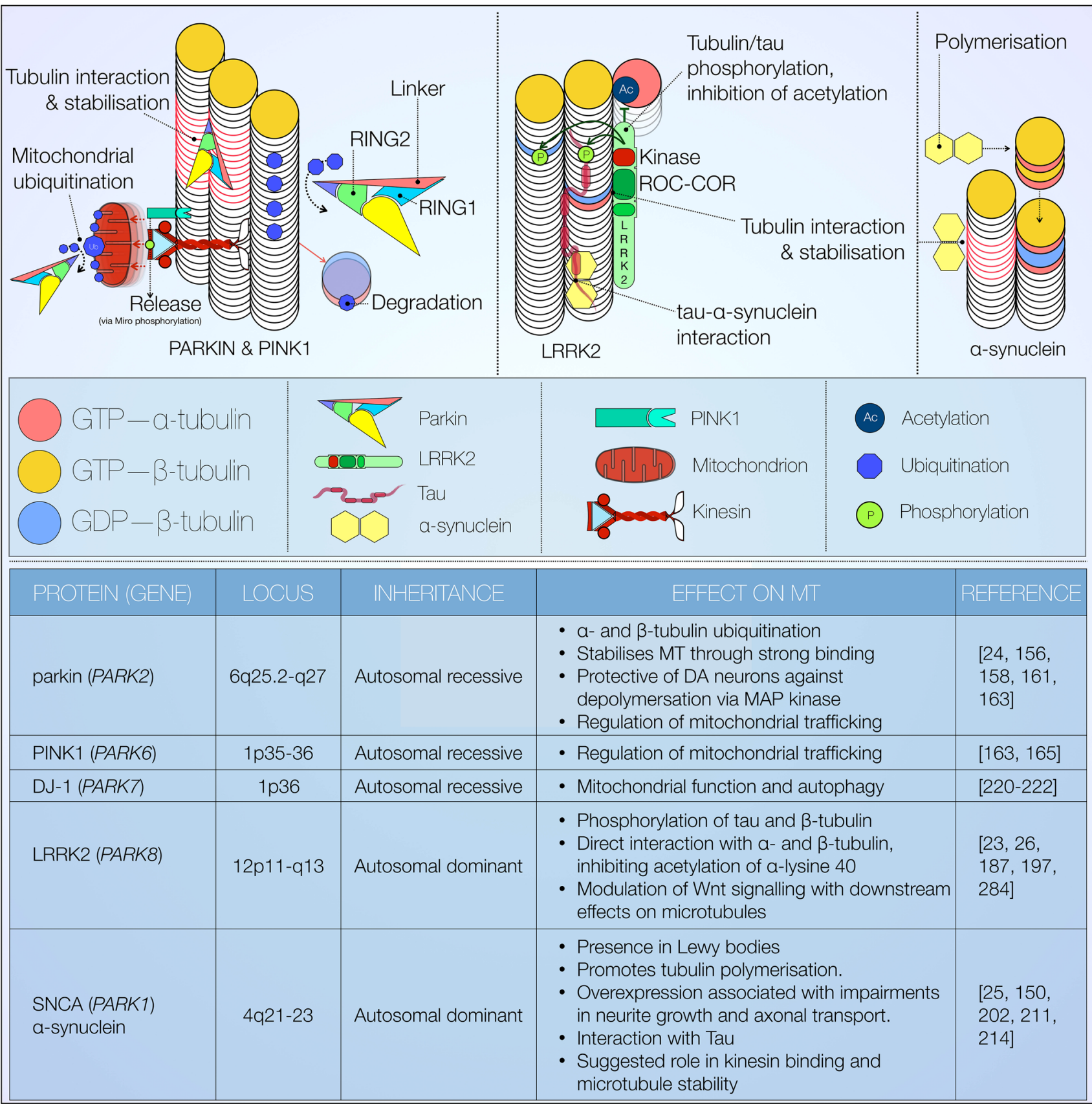

Fig. 5 Effect of PD-linked proteins on microtubules. Overview of microtubule effects mediated by mutations in known PD-related genes, including inheritance patterns. All of the discussed proteins

mitochondrial transport arrest may serve as 'quality control', restricting motility to functional mitochondria [163]. It has been in fact previously shown that PINK1 is selectively cleaved into $\triangle \mathrm{N}$-PINK1 at active mitochondrial surfaces and subsequently degraded [173-175]. Interestingly, $\Delta \mathrm{N}$-PINK1 may also bind parkin to provide negative feedback inhibition of mitophagy. Together, these findings suggest mitochondrial activity may be an essential requirement for its efficient transport. This suggests that have demonstrated varying degrees of tubulin binding and the ability to modify microtubule function via several distinct mechanisms. Parkin structure adapted from [160]

PD-linked loss of function mutations in PINKI and parkin allow aberrant transport of dysfunctional mitochondria, a process likely deleterious to neuronal viability in the long term. The precise molecular mechanism by which PINK1 and parkin regulate mitochondrial transport and ubiquitination endogenously remains elusive, however [176]. Upstream of PINK1, the serine/threonine MAP/microtubule affinity regulating kinase 2 (MARK2) has been identified as a regulatory enzyme [177]. Phosphorylation of 
the cleavage product $\Delta \mathrm{N}-\mathrm{PINK} 1$ by MARK2 was shown to promote anterograde mitochondrial motility [177, 178]. The authors also employ imaging to report PINK1 and MARK2 co-localisation with mitochondria, predominately within axons and dendrites. Whilst lacking a mitochondrial localisation signal, $\triangle \mathrm{N}$-PINK1 has also been shown to influence dendrite but not axonal morphology via interaction with MAP2 [179, 180].

Leucine-rich repeat kinase 2 (Fig. 5, centre) is another example of a microtubule-interacting protein with relevance to PD. Encoded by $L R R K 2$, it is a large protein with overlapping functions in microtubule dynamic and intracellular signalling. LRRK2 contains kinase and GTPase (Roc-COR) domains, as well as multiple protein-protein interaction sites [181]. Mutations and variants in LRRK2 are implicated in both autosomal dominant and sporadic PD [157, 182, 183]. All pathogenic mutations are located in the LRRK2 Roc-COR GTPase or LRRK2 kinase domain, and encompass single amino acid substitutions.

One of the most consistently observed effects of LRRK2 mutations on the cytoskeleton is impaired neurite outgrowth [53, 184, 185]. Nonetheless, it is unclear if this is due to LRRK2 mediated changes in tubulin phosphorylation, tubulin acetylation, MAP phosphorylation and/or microtubule associated protein kinase regulation. Early in vitro experiments in HEK293 cells revealed LRRK2 colocalisation with $\beta$-tubulin [186]. We have also previously shown LRRK2 co-localisation with microtubules in growth cones [23, 187]. In this subcellular compartment, LRRK2 may also regulate the balance between stabilised and destabilised actin filaments [188]. Gillardon further reported that LRRK2 phosphorylates bovine brain $\beta$-tubulin [189]. Interestingly, phosphorylation was enhanced significantly by the pathogenic G2019S mutation in the LRRK2 kinase domain conferring increased LRRK2 autophosphorylation. We later demonstrated LRRK2 binding to the $\mathrm{C}$-termini of only three out of eight $\beta$-tubulin isoforms possibly conferring some specificity in subcellular microtubule binding of LRRK2 [23]. Interestingly, this protein interaction takes place at the luminal microtubule surface in close proximity to the taxol binding site on $\beta$ tubulin and the lysine $40 \alpha$-tubulin acetylation sites. LRRK2 knockout was further shown to increase $\alpha$-tubulin acetylation indicating that LRRK2 binding to microtubules might interfere with tubulin acetylation. In addition, we showed that the $\beta$-tubulin LRRK2 protein interaction strength was modulated by LRRK2 mutations. Surprisingly, some mutations increased, whereas others decreased the protein interaction indicating that a fine regulation of this interaction might be required in order to avoid too much as well as too little $\alpha$-tubulin acetylation [23]. Godena et al. more recently showed that both LRRK2 R1441C and Y1699C selectively bind deacetylated microtubules in vitro
[26]. They suggested that this correlated to the observed mutation-dependent alterations in axonal transport in rat cortical neurons. Moreover, cells overexpressing mutant LRRK2 showed LRRK2 co-localisation with tubulin in filamentous structures. These mutants also altered axonal transport and induced motor impairments in Drosophila [26]. The LRRK2 kinase inhibitor IN-1 has now been reported to decrease $\alpha$-tubulin acetylation and reduce microtubule stability in hybrid human cells [190]. A corresponding increase in free $\alpha$-tubulin was also observed, consistent with microtubule depolymerisation.

In addition to tubulin, several lines of evidence suggest a functional interaction between LRRK2 and tau [191]. Tau neuropathology was reportedly observed in some human PD brains expressing the Y1699C, G2019S and I2020T LRRK2 mutations [182, 192-194]. Age-related tau mislocalization and hyperphosphorylation have also been described in transgenic mice carrying the LRRK2 G2019S or R1441G mutations [195, 196]. Importantly, Kawakami et al. described LRRK2-mediated tau phosphorylation at threonine 181 in vitro [184]. This reaction appears to be limited to tubulin-associated tau, and results in decreased tubulin binding. The authors propose a model, whereby LRRK2 controls tau release from microtubules through phosphorylation. The notion of a pathophysiological tauLRRK2 interaction was corroborated in a further study by Bailey et al. [197]. They demonstrated LRRK2-mediated tau phosphorylation at a variety of residues in vitro. In addition, in a tau P301L mouse model, expression of LRRK2 significantly increased deposition of insoluble, hyperphosphorylated tau [197]. LRRK2 has also been found to promote GSK3 $\beta$ activity and enhance tau phosphorylation [198, 199]. The above observations are in line with a tau mediated microtubule destabilising effect of LRRK2 mutations.

$S N C A$, encoding $\alpha$-synuclein (Fig. 5, top right), was the first gene in which PD-linked dominant mutations were identified [200]. In addition, duplications and triplications of SNCA were also found to induce clinically diverse parkinsonian symptoms, suggesting a gene dose-dependent pathogenic effect [200, 201]. $\alpha$-Synuclein accumulates and aggregates in Lewy bodies, the classical pathological hallmark of PD. These aggregates consist of a misfolded $\alpha$ synuclein core surrounded by other proteins. A number of proteins have been found to co-localise with $\alpha$-synuclein within Lewy bodies-namely tau, ubiquitin, tubulin as well as synaptic vesicle and stress-response proteins [202-204]. Some studies have also demonstrated presence of LRRK2, suggesting an interaction with $\alpha$-synuclein [205, 206]. LRRK2 has further been suggested as upstream of either $\alpha$ synuclein and/or tau phosphorylation [207]. This hypothesis is supported by LRRK2, $\alpha$-synuclein and tau all representing genetic risk factors for sporadic PD [154, 205]. 
At present, neuronal $\alpha$-synuclein function is understood incompletely. Several studies ascribe a physiological role of $\alpha$-synuclein in the regulation of vesicle transport and dopamine release $[208,209]$. $\alpha$-Synuclein has been shown to interact with tubulin. Nonetheless, the effect of this interaction on tubulin polymerization and microtubule stability is less clear, with some studies suggesting a resulting increase in tubulin polymerisation whereas others suggest an impairment of polymerization [25, 210-212]. The result of $\alpha$-synuclein treatment on neurite outgrowth is similarly inconclusive. Neurite outgrowth was reported to be enhanced in neurons treated with or overexpressing wild-type $\alpha$-synuclein but not mutant forms of the protein [213]. By contrast, overexpression of wild-type and mutant $\alpha$-synuclein has also been implicated in impaired neurite outgrowth, microtubule-dependent axonal transport, autophagy defects, and subsequent axonal degeneration [214]. Koch et al. suggest that the previously reported increase in neurite outgrowth [213] might in fact represent an acute response to exogenous $\alpha$-synuclein expression. Conversely, chronically elevated levels of the protein would result in reduction of neurite length [214]. Interestingly, actin microfilaments and neurofilaments remained unaltered in another study reporting $\alpha$-synuclein induced axonal degeneration [210]. To support this observation, the authors suggested a microtubule-selective mechanism for $\alpha$-synuclein toxicity. On the other hand, tubulin oligomers reportedly stimulate $\alpha$-synuclein fibrillogenesis [203].

Mutations in SNCA result in increased formation of $\alpha$ synuclein $\beta$-sheet structures, resulting in the formation of toxic oligomers and mature fibrils [215]. In vivo design and biophysical analysis of fibril-promoting versus oligomer-promoting variants of $\alpha$-synuclein reveals an important distinction. While $\alpha$-synuclein oligomers correlate with neurotoxicity, the mature fibrils appear to be protective [216]. Accordingly, microtubule depolymerisation induced by mitochondrial dysfunction led to $\alpha$ synuclein oligomerisation supporting the idea of an interdependence of changes in $\alpha$-synuclein expression, microtubule depolymerisation and $\alpha$-synuclein oligomerisation [217]. $\alpha$-Synuclein has also been found to affect axonal transport, influencing microtubule stability and kinesin binding [211]. Consistent with their associated toxicity, $\alpha$-synuclein oligomers significantly impair kinesin function. In a rat model of $\alpha$-synucleinopathy, altered levels of presynaptic and axonal transport protein have also been observed [218].

Genome-wide association studies also highlighted a link between SNCA and MAPT, suggesting cooperation in idiopathic PD pathogenesis [154]. Synucleinopathies with tau-containing inclusions and vice versa have been reported, suggesting toxic interaction between tau and $\alpha$ synuclein. Cross talk between these two proteins promotes synuclein fibrillization and increases tau phosphorylation in vitro and in vivo [219]. A direct interaction between $\alpha$ synuclein and tau has also been shown [150]. Moreover, PD-inducing neurotoxins increase $\alpha$-synuclein expression and downstream synuclein-dependent tau phosphorylation via PKA and GSK3 $\beta[152,212]$. The molecular interplay between $\alpha$-synuclein, microtubules and tau remain a critical question.

Finally, the potential interplay between DJ-1 and microtubules is of note. DJ-1 function is still poorly characterised, and the majority of studies have focused on effects on mitochondrial function. Current evidence implicates loss of DJ-1 in mitochondrial fragmentation, autophagy and oxidative stress [220, 221]. PINK1/parkininduced parkinsonian phenotypes are not rescued by $D J-1$ expression, suggesting potentially independent pathomechanisms [221]. A function for DJ-1 in microtubule dynamics has recently been revealed. siRNA-mediated knockdown of DJ-1 resulted in reduced $\beta$-tubulin III expression in neuroblastoma cells [222]. Importantly, a similar phenotype was observed in DJ-1 knockout mice. In both DJ-1 deficient model systems, microtubule polymerisation was reduced. Abnormal dendritic morphology was additionally observed in cultured striatal medium spiny neurons [222]. While these results offer promising insights into DJ-1 function on microtubules, extensive investigation into its potential relationship with previously discussed pathomechanisms is required.

The majority of experiments on the interaction of the cytoskeleton and familial PD proteins support the idea of a role of these proteins in the regulation of microtubule dynamics by different mechanisms including changes in PTMs of tubulin and tau, and changes in the activity of tau kinases. These observed changes can result in microtubule depolymerisation, subsequent impairment of axonal transport, synaptic dysfunction and eventually neurodegeneration. As the first insult seems to be a loss of fine regulation of the dynamic instability of microtubules the idea to use therapeutics strategies that restore this equilibrium is justified.

\section{Potential therapeutic strategies}

Mounting evidence points to cytoskeletal dysfunction as an underlying mechanism in neurodegenerative diseases, including PD. Microtubule-oriented therapeutic approaches have been among the most successful in cancer therapy [223-225]. Several authors now also indicate microtubules as promising targets in neurodegenerative diseases [226, 227]. Here, we present potential therapeutic strategies, focusing on microtubule modulation and control of cellular signalling. 
Microtubule-targeting agents (MTAs) are a group of compounds, which variably bind to and modify microtubule function (Fig. 6). Depending on their effect on polymerisation, they are classified as microtubule stabilising or destabilising agents. A number of MTAs are in various stages of preclinical and clinical development [225]. Examples discussed here include the taxanes, epothilone D and noscapine.

Members of the taxane family of compounds are amongst the better characterised MTAs. Paclitaxel (Taxol ${ }^{\circledR}$ ) was first isolated from T. brevifolia in 1971 [228] and later identified as a microtubule binding, antimitotic agent [229-233]. Prolonged paclitaxel treatment has long been shown to induce microtubule stabilisation and $\alpha$ tubulin acetylation [234]. This finding is suggestive of a mechanism whereby stabilised microtubules might facilitate acetyltransferase access to lysine 40. Given the importance of tubulin acetylation in recruitment of motor proteins [90, 101, 102], enhanced microtubule stability may constitute a requirement for efficient axonal transport. A definitive mechanism for paclitaxel-induced microtubule stabilisation was proposed in more recent years, ascribing its effect to luminal $\beta$-tubulin binding. Such interaction induces lateral protofilament stabilisation following a conformational change at the $\beta$-tubulin M-loop [235, 236]. The subsequently named taxane binding site has been the focus of extensive investigation into a number of compounds with similar binding properties. Two prominent examples are the epothilones (see below) and zampanolide, with X-ray crystallography confirming reversible and covalent binding to the taxane site, respectively [229, 237]. With relevance to neurodegeneration, selective dopaminergic loss in rotenone-induced Parkinsonism is reversed by paclitaxel $[162,235]$. The outcomes of paclitaxel treatment on axonal transport are diverse, however, and still under debate. A study by Karbowski et al. has in fact shown that paclitaxel-induced microtubule stabilisation does not affect intracellular trafficking and distribution of mitochondria [238]. Conversely, paclitaxel restored alterations in fast axonal transport, microtubule detyrosination as well as motor deficits in tau transgenic mice [139]. An intriguing explanation for this effect was proposed by the authors, whereby paclitaxel does not reduce the pathological burden of tau inclusions per se. Rather, this compound acts as a functional replacement for sequestered tau [139]. Interestingly, the taxane binding site is also targeted by the microtubule-binding domain of tau, with paclitaxel inducing tau displacement from microtubules [236, 239]. Despite such effectiveness, a major challenge to paclitaxel administration is posed by its very poor penetrance of the blood-brain barrier [240]. To address this issue, synthetic paclitaxel derivates with an improved delivery profile have been developed. Examples include cabazitaxel, TPI-287, and IDN-5109 [241-245]. The paclitaxel-peptide conjugate, GRN1005, a paclitaxel-peptide conjugate, was also recently developed to enhance neuronal delivery. Following administration in patients with advanced solid tumours, the active paclitaxel-GRN1005 complex was detected within brain metastases [246].

The epothilone family of taxol-like compounds comprises blood-brain barrier-penetrant microtubule stabilising agents which have recently been a research focus in cancer and neurodegeneration [103, 240, 247]. Similarly to paclitaxel, their efficacy is thought to originate from functional replacement of tangle-sequestered tau. Longterm epothilone D (Epo D) treatment at subcytotoxic doses restored axonal morphology and microtubule density to wild-type levels in young PS19 tau transgenic mice. ADlike cognitive impairments associated with this murine model were also ameliorated [248]. Similar results were later obtained in aged PS19 mice, in which Epo D rescued axonal transport defects and improved cognition [249]. Both studies demonstrate the absence of dose-limiting side effects, indicating Epo D as a promising candidate for neurodegeneration therapy. Cartelli et al. later investigated a similar treatment regimen in a 1-methyl-4-phenyl1,2,3,6-tetrahydropyridine (MPTP) murine model of PD [103]. These mice display nigrostriatal degeneration with early PTM alterations in $\alpha$-tubulin. Dopaminergic loss, as well as the altered PTMs was both ameliorated following systemic, long-term Epo D injections [103]. The authors argue that disruption of neuronal microtubule dynamics may constitute an early, preclinical event in PD pathogenesis, supporting the notion of microtubule stabilisation as a valid therapeutic approach. A recent study has further highlighted the neuroprotective properties of Epo D [250]. In vitro modelling of axonal transection injury now demonstrates a dose-dependent enhancement of post-injury recovery. Particularly, Epo D improves axonal sprout number significantly while growth kinetics remains unaffected. The authors also report cultured neurons to remain viable throughout a wide dose range. This observation confirms the relatively low toxicity of Epo D doses at which microtubule-stabilising effects can be achieved.

Noscapine, an opium alkaloid with established antitussive effects [251], is another interesting candidate due to reported, albeit weak, microtubule-modifying properties [252-254]. While noscapine does not appear to significantly affect microtubule polymerisation or overall amounts of intracellular tubulin, it has been characterised as tubulin-binding compound in vitro [253, 255]. Additionally, a number of noscapine-mediated neuroprotective effects have been observed. In a SOD1 transgenic mouse model of ALS, microtubule and axonal transport deficits are reportedly improved following noscapine treatment [247]. Particularly, a significant reduction in microtubule 


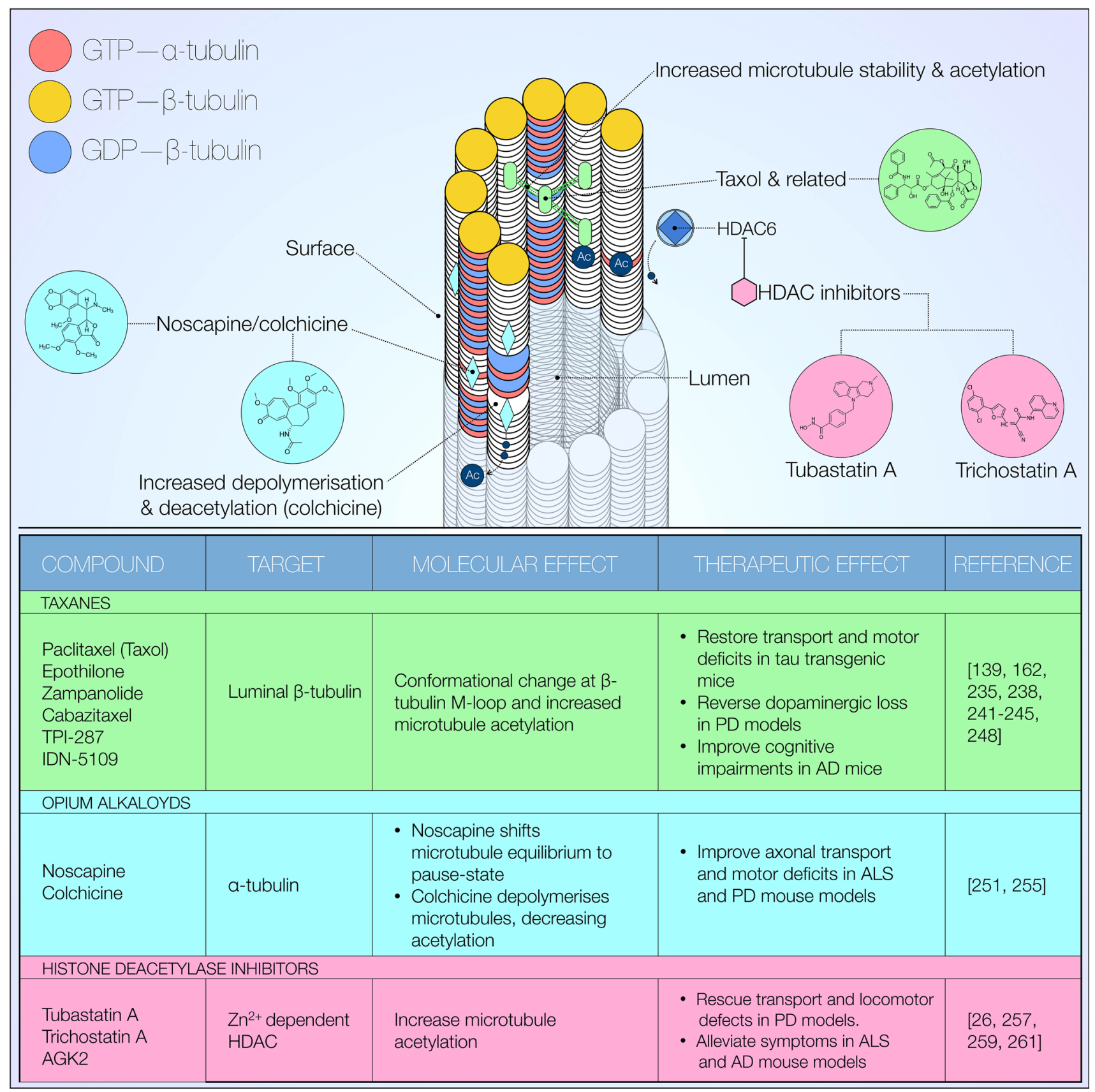

Fig. 6 Microtubule-targeting agents (MTAs). Overview of microtubule targeting agents as potential therapeutic strategies. A variety of compounds has been shown to exert beneficial effects on microtubule PTMs, stability and transport. Additionally, the outlined agents are all

turnover rate was observed in association with delayed disease onset and improved motor behaviour. Further experiments by this group later characterised axonal transport-mediated cerebrospinal fluid (CSF) secretion of a number of known cargo proteins, including $\alpha$-synuclein and APP [256]. PD patients displayed CSF secretion profiles consistent with significant alterations in cargo transport dynamics. This observation was paralleled in reportedly able to produce improvements in PD-associated, model phenotypes. MTAs are also characterised by low toxicity at microtubule-modifying doses [Reference for chemical structures: https:// www.ncbi.nlm.nih.gov/pccompound]

MPTP-treated as well as A53T SNCA mutant mice. Interestingly, noscapine treatment significantly improved the CSF phenotype [256].

Considering the importance of tubulin acetylation in maintenance of intracellular transport [90, 101], pharmacological modulation of this PTM may prove useful in PD treatment. Histone deacetylase inhibitors (Fig. 6) have long been employed in psychiatry, and in more recent years as 
antimitotic agents. Because of the functional overlap of histone acetyltransferases in structural control of both chromatin and tubulin, the aforementioned class of compounds has indeed proven capable of altering microtubule function. Treatment of hippocampal neurons with trichostatin A, a histone deacetylase I-II inhibitor, has been shown to direct kinesin-1-mediated JIP1 transport to neurite tips [102]. A recent study characterised microtubule dysfunction in Rett syndrome, a rare neurodevelopmental condition [257]. In patient-derived fibroblasts, reduced $\alpha$ tubulin acetylation was observed in correlation with increased expression of HDAC6. Additionally, microtubule polymerisation was markedly decreased. A similar phenotype was also observed in Rett syndrome mouse models. Administration of tubastatin A, an HDAC6 inhibitor, was then investigated. Within both model systems, pharmacological inhibition of HDAC6 restored $\alpha$-tubulin acetylation levels. The polymerisation phenotype was also ameliorated, albeit to a more limited extent [257]. Taken together, these compelling data suggest targeting of deacetylated $\alpha$ tubulin as a promising therapeutic strategy in Rett syndrome. Translating this approach to PD, however, demands further insight into a potential microtubule-mediated pathomechanism.

In this respect, the study by Godena et al. introduced in the previous section is of relevance [26]. Drosophila axonal transport and locomotor deficits induced by PDassociated LRRK2 mutations were reversed by trichostatin A, tubastatin A or AGK2, a SIRT2 inhibitor [26]. As mentioned previously, abnormal filamentous LRRK2 was detected in marked co-localisation with tubulin. These aberrant structures were suppressed by deacetylase inhibitor treatment in HEK293 cells and rat cortical neurons. Furthermore, $\alpha$ TAT1 expression also prevents the mutant phenotype [26]. In accordance with these data, another study reports on a partial phenotype rescue in a 1-methyl-4phenylpyridinium $\left(\mathrm{MPP}^{+}\right)$-induced zebrafish $\mathrm{PD}$ model [258]. This fish suffers from impaired locomotion and sensorimotor reflexes, as well as lowered cellular metabolic rate. Both tubastatin A and MS-275-a synthetic HDAC1 inhibitor-rescued the metabolic phenotype. Both inhibitors, however, failed to improve locomotion [258]. The authors thus highlight the need for further studies in models of genetically induced PD to clarify potential confounding factors. In the wider context of neurodegeneration, mouse models of ALS [259], AD [260] and Charcot-Marie-Tooth (CMT) disease [261] may also benefit from HDAC6 inhibition. In all cases, deacetylase inhibitor therapy resulted in symptomatic alleviation. However, it should be noted that oxidative stress induced by the neurotoxin 60HDA also reduces deacetylase activity via inhibition of SIRT2 [94]. This finding indicates that therapeutic effects of deacetylase inhibition may be context-dependent. An emerging trend suggests that control over cellular signalling pathways upstream of microtubule function might also constitute an effective therapeutic approach in neurodegenerative disease. Here, we present evidence on two key pathways: neurotrophic factor-dependent and Wingless/Int1 (Wnt) signalling.

Accumulating evidence increasingly supports modulation of neurotrophic factors (NTFs) as a potential strategy in protecting dopaminergic neurons from insult [262-264]. Jiang et al. evaluated the neuroprotective effects of three common NTFs: nerve growth factor (NGF), BDNF and glia cell line-derived neurotrophic factor (GDNF) [265]. The authors employed rotenone and colchicine-mediated modelling of dopaminergic loss in cultured midbrain neurons. These model systems display extensive microtubule depolymerisation and death of tyrosine hydroxylase-positive neurons. Such phenotype further reiterates the importance of a functional microtubule network in neuronal viability. In all cases, neurotrophic factor treatment significantly attenuated toxicity and restored microtubule polymerisation. The latter effect is ascribed by the authors to activation of microtubuleassociated protein kinase kinase (MEK). Conversely, MEK inhibition abolished NTF-mediated neuroprotection [265].

To date, several clinical trials have investigated GDNF treatment in PD patients [262, 266]. However, results have so far been inconclusive [267]. In 2006, Salvatore et al. highlighted difficulties in midbrain drug delivery as a potential explanation for inefficacy of GDNF [268]. More recent work investigating viral vectors for sustained NTF delivery has offered promising results [269]. A number of studies have also investigated the effect of HDAC inhibitors on NTF gene expression. Valproate, known as antiepileptic agent, reportedly increases GDNF and BDNF expression in midbrain neuronal-astrocyte cultures by targeting HDAC2 [270]. Neuroprotection from $\mathrm{MPP}^{+}$toxicity was achieved concomitantly. A similar outcome was later observed with an expanded range of HDAC inhibitors [271]. Due to the relatively broad spectrum of enzyme inhibition of HDAC inhibitors, it is worth pointing out that enhanced NTF gene expression might result from a histone-dependent mechanism unrelated to microtubules. A comparative analysis of expression profiles under a range of MTA treatments could offer insight into this mechanism.

Three independent highly conserved Wnt signalling pathways have been described: the canonical pathway plays key roles in gene expression via transcriptional activation of $\beta$-catenin, the noncanonical/planar cell polarity pathway (PCP) controls cytoskeletal rearrangement in development through activation of Rho GTPase and Jun N-terminal kinase (JNK) and the $\mathrm{Wnt} / \mathrm{Ca}^{2+}$ pathway modulates cytosolic calcium levels [181, 272]. Although functionally distinguishable, all three share sensitivity to the Wnt family of ligands. 
Wnt signalling exerts control over microtubule dynamics [181, 273] and midbrain dopaminergic neuronal development [274]. The pathway is generally well characterised in the context of nervous system development. Its finely regulated activity provides axonal guidance and remodelling, control of dendrite morphology and synapse formation [275, 276]. Interestingly, all of these mechanisms are heavily dependent on cytoskeletal function [277]. In this respect, Wnt-mediated regulation of cell polarity has been characterised in mouse embryonic fibroblasts [278]. The authors indicate that GSK3 $\beta$, dishevelled (DVL) and axin-three key Wnt components-are required for translocation of the centrosome to the leading edge of polarising cells. Additionally, adenomatous polyposis coli (APC), a further Wnt protein, were previously revealed to accumulate and bind to microtubule plus ends [279]. Moreover, APC interaction with membrane components leads to microtubule polarisation [280]. In embryonic neuronal tissue, Wnt signalling appears to interact with actin-microtubule tethering mechanisms [281]. This process is reportedly mediated by microtubule actin crosslinking factor 1 (MACF1). Homozygous silencing of the corresponding gene is lethal early in embryonic development. The authors describe a phenotype similar to ablation of Wnt ligand production. Moreover, MACF1 was revealed to participate in translocation of key Wnt components to the membrane in a putative microtubule-dependent process [281].

Some of the PD-related proteins, discussed previously, have been reported to affect Wnt signalling-namely parkin [282], PINK1 [283] and LRRK2 [187, 284]. For the latter, multiple interactions have been described. LRRK2 appears to bind low density lipoprotein receptor-related protein 6 (LRP6), axin1, GSK3 $\beta, \beta$-catenin and DVL 1-3 [187, 284]. Consequently, it was proposed to serve as a scaffolding protein facilitating Wnt signalling activation [284]. Indeed, expression of LRRK2 directly enhances $\beta$ catenin transcriptional activity [54, 284]. The aforementioned PD-associated, Roc-COR LRRK2 mutations appear to partly abolish this effect while modulating LRRK2LRP6 interaction [54]. Interestingly, Godena et al. reported on axonal transport disruption and locomotor defects induced by these mutations, as previously discussed [26]. By inference, microtubule/LRRK2/Wnt interplay might indeed constitute an additional candidate mechanism for molecular regulation of axonal transport [23, 191, 285]. Further investigation is required to establish the extent of this interaction, for instance, by determining whether the LRRK2 mutation-mediated effects on Wnt signalling can be rescued by microtubule-stabilising therapy. Investigators also propose pharmacological modulation of the Wnt signalling pathways as a potential strategy in PD treatment $[274,286]$. These pathways are extremely complex, however, and target diverse cellular mechanisms. Their functional heterogeneity is a potential confounding factor, and needs to be taken into account when investigating cellwide effects of Wnt signalling modulation.

\section{Discussion and concluding remarks}

We have discussed key evidence surrounding microtubule dysfunction in neurodegenerative disease, with particular focus on PD. A multitude of proteins and pathways of varying functional relationships with microtubules seem to be implicated in parkinsonian phenotypes. PD-linked proteins involved are associated with mitochondrial transport $[163,165]$, microtubule assembly and stability [25, 211], dynamics [187] and association of motor proteins [141]. Furthermore, their aberrant activity results in impairment of axonal transport, neurite outgrowth and generally induces morphological abnormalities in neurons [26, 54]. All of these proteins are able to interact with microtubules, either directly or via adaptor and motor proteins. Arguably, any protein which is transported along microtubules will ultimately bind them through a variety of mechanisms. In relation to $\mathrm{PD}$, this line of reasoning warrants the following question: Is the specific function of the involved proteins the primary cause of toxicity, or do transport defects induce pathology downstream?

To initially address this issue, we propose a 'traffic wave' model of microtubule dysfunction in PD, and by extension, neurodegenerative disease. This constitutes an attempt to account for the diversity of microtubule-associated processes which lead to impaired neuronal function. Traffic wave disturbances in travel propagate and intensify retrogradely in relation to traffic direction. Generally, they result in perturbations significantly larger than the initial 'insult', and travel backwards for extended distances. We propose that a similar phenomenon, or rather the long-term accumulation of transportation defects, may ultimately result in (a) disruption of cytoskeletal architecture and (b) loss of functional localisation of any protein or organelle whose transport is secondarily delayed/affected.

There are a number of observations which lend credibility to this line of reasoning. As previously discussed, both tau and $\alpha$-synuclein associate with microtubules and tau has been shown to promote axonal transport $[25,139,140,213]$. Tau exerts an antagonistic action on motor protein binding. Its functional loss due to aggregation could therefore induce excessive motor protein binding. This may also subsequently result in higher amounts of motor-bound cargo. Accumulation of motor proteins may reduce transport speed and propagate retrogradely as a concentration gradient. Indeed motor protein gradients are known to directly determine the directionality 
of microtubule transport and movement [287]. The alternation between anterograde and retrograde transport is dependent on relative concentrations of dynein and kinesin. Uncoordinated directional switches caused by altered gradients may decrease transport efficiency. This might ultimately lead to an unpredictable array of functional consequences. One prominent example could be delay in delivery of functional mitochondria, depriving parts of the cell of efficient energy production. Considering that molecular motors are dependent on local ATP gradients [115], retrogradely propagating changes in energy availability may also progressively reduce the ability of microtubules to deliver cargo to subcellular compartments. In addition, changes in tau or $\alpha$-synuclein phosphorylation state are known to affect microtubule polymerisation [137]. A slower polymerising microtubule may induce accumulation of anterograde cargo at the plus end. This might in turn propagate backwards along the microtubule and further impair transport.

The discussed LRRK2-mediated effects might also aid corroboration of this model. For example, Godena et al. demonstrated a mutation-dependent decrease in axonal trafficking [26]. At the same time, however, mutant LRRK2 was seen in close association to microtubules, far more so than WT LRRK2. It may be argued that axonal transport is slowed down by actual physical interference of mutant LRRK2 with the microtubule network which, in turn, retrogradely propagates delays in transport. Given the discussed importance of fine regulation of tubulin PTMs, a cargo-crowded microtubule might indeed be more impervious to enzymatic access. Changes in acetylation or phosphorylation status, for instance, might propagate retrogradely and ultimately destabilise microtubules.

The current outlook on therapeutic strategies is also of relevance. Most, if not all microtubule-oriented approaches share a common principle: stabilisation of microtubules appears to be beneficial [226, 227]. While these agents do not necessarily target the pathological burden of PD-linked proteins-e.g., aggregate formation-they do restore appropriate axonal transport and consequently ensure cargo delivery. Their beneficial effects might therefore be due to maintenance of functional localisation of virtually any protein transported along microtubules.

In conclusion, intracellular transport alterations may induce secondary damage not always in functional relation to the protein originally causing the defects. Amongst all cell types, neurons are some of the most heavily dependent on a functional microtubule network. PD-linked proteins may, however diverse, be dependent on a shared, microtubule-dependent pathway. Therefore, development of effective therapies aimed at maintaining a functional cytoskeleton may constitute an effective approach.
Open Access This article is distributed under the terms of the Creative Commons Attribution 4.0 International License (http:// creativecommons.org/licenses/by/4.0/), which permits unrestricted use, distribution, and reproduction in any medium, provided you give appropriate credit to the original author(s) and the source, provide a link to the Creative Commons license, and indicate if changes were made.

\section{References}

1. Kalia LV, Lang AE (2015) Parkinson's disease. Lancet 386:896-912

2. Albin RL, Young AB, Penney JB (1989) The functional-anatomy of basal ganglia disorders. Trends Neurosci 12:366-375

3. de Lau LM, Breteler MM (2006) Epidemiology of Parkinson's disease. Lancet Neurol 5:525-535

4. Reeve A, Simcox E, Turnbull D (2014) Ageing and Parkinson's disease: why is advancing age the biggest risk factor? Ageing Res Rev 14:19-30

5. Mehanna R, Moore S, Hou JG, Sarwar AI, Lai EC (2014) Comparing clinical features of young onset, middle onset and late onset Parkinson's disease. Parkinsonism Relat Disord 20:530-534

6. Chartier-Harlin MC, Kachergus J, Roumier C, Mouroux V, Douay X, Lincoln S, Levecque C, Larvor L, Andrieux J, Hulihan M, Waucquier N, Defebvre L, Amouyel P, Farrer M, Destee A (2004) alpha-synuclein locus duplication as a cause of familial Parkinson's disease. Lancet 364:1167-1169

7. Ibanez P, Bonnet AM, Debarges B, Lohmann E, Tison F, Pollak P, Agid Y, Durr A, Brice A (2004) Causal relation between alpha-synuclein gene duplication and familial Parkinson's disease. Lancet 364:1169-1171

8. Hardy J (2010) Genetic analysis of pathways to Parkinson disease. Neuron 68:201-206

9. Nutt JG, Wooten GF (2005) Clinical practice. Diagnosis and initial management of Parkinson's disease. N Engl J Med 353:1021-1027

10. Chaudhuri KR, Schapira AHV (2009) Non-motor symptoms of Parkinson's disease: dopaminergic pathophysiology and treatment. Lancet Neurol 8:464-474

11. Wakabayashi K, Tanji K, Mori F, Takahashi H (2007) The Lewy body in Parkinson's disease: molecules implicated in the formation and degradation of alpha-synuclein aggregates. Neuropathology 27:494-506

12. Lynch-Day MA, Mao K, Wang K, Zhao M, Klionsky DJ (2012) The role of autophagy in Parkinson's disease. Cold Spring Harb Perspect Med 2:a009357

13. Hirsch EC, Vyas S, Hunot S (2012) Neuroinflammation in Parkinson's disease. Parkinsonism Relat Disord 18(Suppl 1):S210-S212

14. Schapira AH (2007) Mitochondrial dysfunction in Parkinson's disease. Cell Death Differ 14:1261-1266

15. Lloyd KG, Davidson L, Hornykiewicz O (1975) Neurochemistry of Parkinson's-disease-effect of L-Dopa therapy. J Pharmacol Exp Ther 195:453-464

16. Hely MA, Morris JGL, Reid WGJ, Trafficante R (2005) Sydney multicenter study of Parkinson's disease: non-L-dopa-responsive problems dominate at 15 years. Mov Disord 20:190-199

17. Saint-Cyr JA, Taylor AE, Lang AE (1993) Neuropsychological and psychiatric side effects in the treatment of Parkinson's disease. Neurology 43:S47-S52

18. Przuntek H, Welzel D, Gerlach M, Blumner E, Danielczyk W, Kaiser HJ, Kraus PH, Letzel H, Riederer P, Uberla K (1996) Early institution of bromocriptine in Parkinson's disease inhibits 
the emergence of levodopa-associated motor side effects. Longterm results of the PRADO study. J Neural Transm (Vienna) 103:699-715

19. Rinne UK (1987) Early combination of bromocriptine and levodopa in the treatment of Parkinson's disease: a 5-year follow-up. Neurology 37:826-828

20. Galloway PG, Mulvihill P, Perry G (1992) Filaments of Lewy bodies contain insoluble cytoskeletal elements. Am J Pathol 140:809-822

21. Olanow CW, Perl DP, DeMartino GN, McNaught KSP (2004) Lewy-body formation is an aggresome-related process: a hypothesis. Lancet Neurol 3:496-503

22. Goldman JE, Yen SH, Chiu FC, Peress NS (1983) Lewy bodies of Parkinson's disease contain neurofilament antigens. Science 221:1082-1084

23. Law BM, Spain VA, Leinster VH, Chia R, Beilina A, Cho HJ, Taymans JM, Urban MK, Sancho RM, Blanca Ramirez M, Biskup S, Baekelandt V, Cai H, Cookson MR, Berwick DC, Harvey K (2014) A direct interaction between leucine-rich repeat kinase 2 and specific beta-tubulin isoforms regulates tubulin acetylation. J Biol Chem 289:895-908

24. Yang F, Jiang Q, Zhao J, Ren Y, Sutton MD, Feng J (2005) Parkin stabilizes microtubules through strong binding mediated by three independent domains. J Biol Chem 280:17154-17162

25. Alim MA, Ma QL, Takeda K, Aizawa T, Matsubara M, Nakamura M, Asada A, Saito T, Kaji H, Yoshii M, Hisanaga S, Ueda $\mathrm{K}$ (2004) Demonstration of a role for alpha-synuclein as a functional microtubule-associated protein. J Alzheimers Dis 6:435-442 (discussion 443-439)

26. Godena VK, Brookes-Hocking N, Moller A, Shaw G, Oswald M, Sancho RM, Miller CC, Whitworth AJ, De Vos KJ (2014) Increasing microtubule acetylation rescues axonal transport and locomotor deficits caused by LRRK2 Roc-COR domain mutations. Nat Commun 5:5245

27. Coles CH, Bradke F (2015) Coordinating neuronal actin-microtubule dynamics. Curr Biol 25:R677-R691

28. Akhmanova A, Hoogenraad CC (2015) Microtubule minus-endtargeting proteins. Curr Biol 25:R162-R171

29. Janke C (2014) The tubulin code: molecular components, readout mechanisms, and functions. J Cell Biol 206:461-472

30. Conde C, Caceres A (2009) Microtubule assembly, organization and dynamics in axons and dendrites. Nat Rev Neurosci 10:319-332

31. Mitchison T, Kirschner M (1984) Dynamic instability of microtubule growth. Nature 312:237-242

32. Desai A, Mitchison TJ (1997) Microtubule polymerization dynamics. Annu Rev Cell Dev Biol 13:83-117

33. Mishra RK, Chakraborty P, Arnaoutov A, Fontoura BMA, Dasso M (2010) The Nup107-160 complex and gamma-TuRC regulate microtubule polymerization at kinetochores. Nat Cell Biol 12:164-169

34. Zheng Y, Wong ML, Alberts B, Mitchison T (1995) Nucleation of microtubule assembly by a gamma-tubulin-containing ring complex. Nature 378:578-583

35. Menendez M, Rivas G, Diaz JF, Andreu JM (1998) Control of the structural stability of the tubulin dimer by one high affinity bound magnesium ion at nucleotide $\mathrm{N}$-site. J Biol Chem 273:167-176

36. Alushin GM, Lander GC, Kellogg EH, Zhang R, Baker D, Nogales E (2014) High-resolution microtubule structures reveal the structural transitions in alpha beta-tubulin upon GTP hydrolysis. Cell 157:1117-1129

37. Gupta KK, Li C, Duan A, Alberico EO, Kim OV, Alber MS, Goodson HV (2013) Mechanism for the catastrophe-promoting activity of the microtubule destabilizer Op18/stathmin. Proc Natl Acad Sci U S A 110:20449-20454
38. Bayley PM, Butler FM, Manser EJ (1986) Control of nucleation in microtubule self-assembly. FEBS Lett 205:230-234

39. Dumontet C, Jordan MA (2010) Microtubule-binding agents: a dynamic field of cancer therapeutics. Nat Rev Drug Discov 9:790-803

40. Maday S, Twelvetrees AE, Moughamian AJ, Holzbaur EL (2014) Axonal transport: cargo-specific mechanisms of motility and regulation. Neuron 84:292-309

41. Wetzel A, Jablonka S, Blum R (2013) Cell-autonomous axon growth of young motoneurons is triggered by a voltage-gated sodium channel. Channels (Austin) 7:51-56

42. Subramanian N, Wetzel A, Dombert B, Yadav P, Havlicek S, Jablonka S, Nassar MA, Blum R, Sendtner M (2012) Role of $\mathrm{Na}(\mathrm{v}) 1.9$ in activity-dependent axon growth in motoneurons. Hum Mol Genet 21:3655-3667

43. Spitzer NC (2006) Electrical activity in early neuronal development. Nature 444:707-712

44. Lowery LA, Van Vactor D (2009) The trip of the tip: understanding the growth cone machinery. Nat Rev Mol Cell Bio 10:332-343

45. Mitchison T, Kirschner M (1988) Cytoskeletal dynamics and nerve growth. Neuron 1:761-772

46. Lin CH, Thompson CA, Forscher P (1994) Cytoskeletal reorganization underlying growth cone motility. Curr Opin Neurobiol 4:640-647

47. Lee S, Kolodziej PA (2002) Short Stop provides an essential link between F-actin and microtubules during axon extension. Development 129:1195-1204

48. Roos J, Hummel T, Ng N, Klambt C, Davis GW (2000) Drosophila Futsch regulates synaptic microtubule organization and is necessary for synaptic growth. Neuron 26:371-382

49. Sanchez-Soriano N, Travis M, Dajas-Bailador F, GoncalvesPimentel C, Whitmarsh AJ, Prokop A (2009) Mouse ACF7 and drosophila short stop modulate filopodia formation and microtubule organisation during neuronal growth. J Cell Sci 122:2534-2542

50. Kalil K, Dent EW (2005) Touch and go: guidance cues signal to the growth cone cytoskeleton. Curr Opin Neurobiol 15:521-526

51. Flynn KC (2013) The cytoskeleton and neurite initiation. Bioarchitecture 3:86-109

52. Stiess M, Bradke F (2011) Neuronal polarization: the cytoskeleton leads the way. Dev Neurobiol 71:430-444

53. MacLeod D, Dowman J, Hammond R, Leete T, Inoue $\mathrm{K}$, Abeliovich A (2006) The familial Parkinsonism gene LRRK2 regulates neurite process morphology. Neuron 52:587-593

54. Nixon-Abell Jonathon, Berwick DC, Grannó S, Spain VA, Blackstone C, Harvey K (2016) Protective LRRK2 R1398H variant enhances GTPase and Wnt signalling activity. Front Mol Neurosci 9:18

55. Gomez-Suaga P, Fdez E, Fernandez B, Martinez-Salvador M, Blanca Ramirez M, Madero-Perez J, Rivero-Rios P, Fuentes JM, Hilfiker S (2014) Novel insights into the neurobiology underlying LRRK2-linked Parkinson's disease. Neuropharmacology 85:45-56

56. Arce CA, Rodriguez JA, Barra HS, Caputto R (1975) Incorporation of L-Tyrosine, L-phenylalanine and L-3,4dihydroxyphenylalanine as single units into rat-brain tubulin. Eur J Biochem 59:145-149

57. Hallak ME, Rodriguez JA, Barra HS, Caputto R (1977) Release of tyrosine from tyrosinated tubulin. Some common factors that affect this process and the assembly of tubulin. FEBS Lett $73: 147-150$

58. Janke C, Bulinski JC (2011) Post-translational regulation of the microtubule cytoskeleton: mechanisms and functions. Nat Rev Mol Cell Biol 12:773-786 
59. Schroder HC, Wehland J, Weber K (1985) Purification of brain tubulin-tyrosine ligase by biochemical and immunological methods. J Cell Biol 100:276-281

60. Ersfeld K, Wehland J, Plessmann U, Dodemont H, Gerke V, Weber K (1993) Characterization of the tubulin-tyrosine ligase. J Cell Biol 120:725-732

61. Szyk A, Deaconescu AM, Piszczek G, Roll-Mecak A (2011) Tubulin tyrosine ligase structure reveals adaptation of an ancient fold to bind and modify tubulin. Nat Struct Mol Biol 18:1250-1258

62. Murofushi H (1980) Purification and characterization of tubulintyrosine ligase from porcine brain. J Biochem 87:979-984

63. Erck C, Peris L, Andrieux A, Meissirel C, Gruber AD, Vernet M, Schweitzer A, Saoudi Y, Pointu H, Bosc C, Salin PA, Job D, Wehland J (2005) A vital role of tubulin-tyrosine-ligase for neuronal organization. Proc Natl Acad Sci U S A 102:7853-7858

64. Marcos S, Moreau J, Backer S, Job D, Andrieux A, BlochGallego E (2009) Tubulin tyrosination is required for the proper organization and pathfinding of the growth cone. PLoS One 4:e5405

65. Liao GJ, Gundersen GG (1998) Kinesin is a candidate for crossbridging microtubules and intermediate filaments-selective binding of kinesin to detyrosinated tobulin and vimentin. J Biol Chem 273:9797-9803

66. Dunn S, Morrison EE, Liverpool TB, Molina-Paris C, Cross RA, Alonso MC, Peckham M (2008) Differential trafficking of Kif5c on tyrosinated and detyrosinated microtubules in live cells. J Cell Sci 121:1085-1095

67. Konishi Y, Setou M (2009) Tubulin tyrosination navigates the kinesin-1 motor domain to axons. Nat Neurosci 12:559-567

68. Gundersen GG, Kalnoski MH, Bulinski JC (1984) Distinct populations of microtubules: tyrosinated and nontyrosinated alpha tubulin are distributed differently in vivo. Cell 38:779-789

69. Khawaja S, Gundersen GG, Bulinski JC (1988) Enhanced stability of microtubules enriched in detyrosinated tubulin is not a direct function of detyrosination level. J Cell Biol 106:141-149

70. Webster DR, Wehland J, Weber K, Borisy GG (1990) Detyrosination of alpha-tubulin does not stabilize microtubules invivo. J Cell Biol 111:113-122

71. Bosson A, Soleilhac JM, Valiron O, Job D, Andrieux A, Moutin MJ (2012) Cap-Gly proteins at microtubule plus ends: Is EB1 detyrosination involved? PLoS One 7:e33490

72. Peris L, Thery M, Faure J, Saoudi Y, Lafanechere L, Chilton JK, Gordon-Weeks P, Galjart N, Bornens M, Wordeman L, Wehland J, Andrieux A, Job D (2006) Tubulin tyrosination is a major factor affecting the recruitment of CAP-Gly proteins at microtubule plus ends. J Cell Biol 174:839-849

73. Kerr JP, Robison P, Shi G, Bogush AI, Kempema AM, Hexum JK, Becerra N, Harki DA, Martin SS, Raiteri R, Prosser BL, Ward CW (2015) Detyrosinated microtubules modulate mechanotransduction in heart and skeletal muscle. Nat Commun 6:8526

74. Paturlelafanechere L, Edde B, Denoulet P, Vandorsselaer A, Mazarguil H, Lecaer JP, Wehland J, Job D (1991) Characterization of a major brain tubulin variant which cannot be tyrosinated. Biochemistry 30:10523-10528

75. Paturlelafanechere L, Manier M, Trigault N, Pirollet F, Mazarguil H, Job D (1994) Accumulation of delta-2-tubulin, a major tubulin variant that cannot be tyrosinated, in neuronal tissues and in stable microtubule assemblies. J Cell Sci 107:1529-1543

76. Edde B, Rossier J, Le Caer JP, Desbruyeres E, Gros F, Denoulet P (1990) Posttranslational glutamylation of alpha-tubulin. Science 247:83-85

77. Alexander JE, Hunt DF, Lee MK, Shabanowitz J, Michel H, Berlin SC, MacDonald TL, Sundberg RJ, Rebhun LI,
Frankfurter A (1991) Characterization of posttranslational modifications in neuron-specific class III beta-tubulin by mass spectrometry. Proc Natl Acad Sci U S A 88:4685-4689

78. Redeker V, Melki R, Prome D, Lecaer JP, Rossier J (1992) Structure of tubulin C-terminal domain obtained by subtilisin treatment - the major alpha-tubulin and beta-tubulin isotypes from pig brain are glutamylated. FEBS Lett 313:185-192

79. Rudiger M, Plessman U, Kloppel KD, Wehland J, Weber K (1992) Class-Ii tubulin, the major brain beta-tubulin isotype is polyglutamylated on glutamic-acid residue-435. FEBS Lett 308:101-105

80. Janke C, Rogowski K, van Dijk J (2008) Polyglutamylation: a fine-regulator of protein function? 'Protein Modifications: beyond the usual suspects' review series. EMBO Rep 9:636-641

81. Janke C, Rogowski K, Wloga D, Regnard C, Kajava AV, Strub JM, Temurak N, van Dijk J, Boucher D, van Dorsselaer A, Suryavanshi S, Gaertig J, Edde B (2005) Tubulin polyglutamylase enzymes are members of the TTL domain protein family. Science 308:1758-1762

82. Regnard C, Fesquet D, Janke C, Boucher D, Desbruyeres E, Koulakoff A, Insina C, Travo P, Edde B (2003) Characterisation of PGs1, a subunit of a protein complex co-purifying with tubulin polyglutamylase. J Cell Sci 116:4181-4190

83. Ikegami K, Heier RL, Taruishi M, Takagi H, Mukai M, Shimma S, Taira S, Hatanaka K, Morone N, Yao I, Campbell PK, Yuasa S, Janke C, MacGregor GR, Setou M (2007) Loss of alphatubulin polyglutamylation in ROSA22 mice is associated with abnormal targeting of KIF1A and modulated synaptic function. P Natl Acad Sci USA 104:3213-3218

84. Campbell PK, Waymire KG, Heier RL, Sharer C, Day DE, Reimann H, Jaje JM, Friedrich GA, Burmeister M, Bartness TJ, Russell LD, Young LJ, Zimmer M, Jenne DE, MacGregor GR (2002) Mutation of a novel gene results in abnormal development of spermatid flagella, loss of intermale aggression and reduced body fat in mice. Genetics 162:307-320

85. Sirajuddin M, Rice LM, Vale RD (2014) Regulation of microtubule motors by tubulin isotypes and post-translational modifications. Nat Cell Biol 16:335-344

86. Bonnet C, Boucher D, Lazereg S, Pedrotti B, Islam K, Denoulet P, Larcher JC (2001) Differential binding regulation of microtubule-associated proteins MAP1A, MAP1B, and MAP2 by tubulin polyglutamylation. J Biol Chem 276:12839-12848

87. Nogales E, Whittaker M, Milligan RA, Downing KH (1999) High-resolution model of the microtubule. Cell 96:79-88

88. Chu CW, Hou F, Zhang J, Phu L, Loktev AV, Kirkpatrick DS, Jackson PK, Zhao Y, Zou H (2011) A novel acetylation of betatubulin by San modulates microtubule polymerization via downregulating tubulin incorporation. Mol Biol Cell 22:448-456

89. Howes SC, Alushin GM, Shida T, Nachury MV, Nogales E (2014) Effects of tubulin acetylation and tubulin acetyltransferase binding on microtubule structure. Mol Biol Cell 25:257-266

90. Hubbert C, Guardiola A, Shao R, Kawaguchi Y, Ito A, Nixon A, Yoshida M, Wang XF, Yao TP (2002) HDAC6 is a microtubuleassociated deacetylase. Nature 417:455-458

91. Zhang Y, Li N, Caron C, Matthias G, Hess D, Khochbin S, Matthias P (2003) HDAC-6 interacts with and deacetylates tubulin and microtubules in vivo. EMBO J 22:1168-1179

92. North BJ, Marshall BL, Borra MT, Denu JM, Verdin E (2003) The human Sir2 ortholog, SIRT2, is an NAD $(+)$-dependent tubulin deacetylase. Mol Cell 11:437-444

93. Patel VP, Defranco DB, Chu CT (2012) Altered transcription factor trafficking in oxidatively-stressed neuronal cells. Biochim Biophys Acta 1822:1773-1782

94. Patel VP, Chu CT (2014) Decreased SIRT2 activity leads to altered microtubule dynamics in oxidatively-stressed neuronal 
cells: implications for Parkinson's disease. Exp Neurol 257:170-181

95. Chalovich EM, Zhu JH, Caltagarone J, Bowser R, Chu CT (2006) Functional repression of cAMP response element in 6-hydroxydopamine-treated neuronal cells. J Biol Chem 281:17870-17881

96. Chu CT, Plowey ED, Wang Y, Patel V, Jordan-Sciutto KL (2007) Location, location, location: altered transcription factor trafficking in neurodegeneration. J Neuropathol Exp Neurol 66:873-883

97. Ledizet M, Piperno G (1987) Identification of an acetylation site of chlamydomonas alpha-tubulin. Proc Natl Acad Sci USA 84:5720-5724

98. Kalebic N, Sorrentino S, Perlas E, Bolasco G, Martinez C, Heppenstall PA (2013) alphaTAT1 is the major alpha-tubulin acetyltransferase in mice. Nat Commun 4:1962

99. Shida T, Cueva JG, Xu Z, Goodman MB, Nachury MV (2010) The major alpha-tubulin K40 acetyltransferase alphaTAT1 promotes rapid ciliogenesis and efficient mechanosensation. Proc Natl Acad Sci U S A 107:21517-21522

100. Diaz JF, Valpuesta JM, Chacon P, Diakun G, Andreu JM (1998) Changes in microtubule protofilament number induced by Taxol binding to an easily accessible site. Internal microtubule dynamics. J Biol Chem 273:33803-33810

101. Falconer MM, Vielkind U, Brown DL (1989) Establishment of a stable, acetylated microtubule bundle during neuronal commitment. Cell Motil Cytoskeleton 12:169-180

102. Reed NA, Cai D, Blasius TL, Jih GT, Meyhofer E, Gaertig J, Verhey KJ (2006) Microtubule acetylation promotes kinesin-1 binding and transport. Curr Biol 16:2166-2172

103. Cartelli D, Casagrande F, Busceti CL, Bucci D, Molinaro G, Traficante A, Passarella D, Giavini E, Pezzoli G, Battaglia G, Cappelletti G (2013) Microtubule alterations occur early in experimental parkinsonism and the microtubule stabilizer epothilone D is neuroprotective. Sci Rep 3:1837

104. Gajdusek DC (1985) Hypothesis: interference with axonal transport of neurofilament as a common pathogenetic mechanism in certain diseases of the central nervous system. N Engl $\mathbf{J}$ Med 312:714-719

105. Higuchi M, Lee VM, Trojanowski JQ (2002) Tau and axonopathy in neurodegenerative disorders. Neuromol Med 2:131-150

106. Jensen PH, Nielsen MS, Jakes R, Dotti CG, Goedert M (1998) Binding of alpha-synuclein to brain vesicles is abolished by familial Parkinson's disease mutation. J Biol Chem 273:26292-26294

107. De Vos KJ, Grierson AJ, Ackerley S, Miller CC (2008) Role of axonal transport in neurodegenerative diseases. Annu Rev Neurosci 31:151-173

108. Goldstein LS (2012) Axonal transport and neurodegenerative disease: can we see the elephant? Prog Neurobiol 99:186-190

109. Schwartz JH (1979) Axonal transport: components, mechanisms, and specificity. Annu Rev Neurosci 2:467-504

110. Millecamps S, Julien JP (2013) Axonal transport deficits and neurodegenerative diseases. Nat Rev Neurosci 14:161-176

111. Weiss P, Hiscoe HB (1948) Experiments on the mechanism of nerve growth. J Exp Zool 107:315-395

112. Kapitein LC, Hoogenraad CC (2011) Which way to go? Cytoskeletal organization and polarized transport in neurons. Mol Cell Neurosci 46:9-20

113. Gibbs KL, Greensmith L, Schiavo G (2015) Regulation of axonal transport by protein kinases. Trends Biochem Sci 40:597-610

114. Vale RD, Reese TS, Sheetz MP (1985) Identification of a novel force-generating protein, kinesin, involved in microtubule-based motility. Cell 42:39-50
115. Gilbert SP, Webb MR, Brune M, Johnson KA (1995) Pathway of processive ATP hydrolysis by kinesin. Nature 373:671-676

116. Hirokawa N, Takemura R (2005) Molecular motors and mechanisms of directional transport in neurons. Nat Rev Neurosci 6:201-214

117. Nakata T, Terada S, Hirokawa N (1998) Visualization of the dynamics of synaptic vesicle and plasma membrane proteins in living axons. J Cell Biol 140:659-674

118. Okada Y, Yamazaki H, Sekineaizawa Y, Hirokawa N (1995) The neuron-specific kinesin superfamily protein Kif1a is a unique monomeric motor for anterograde axonal-transport of synaptic vesicle precursors. Cell 81:769-780

119. Dumontet C, Sikic BI (1999) Mechanisms of action of and resistance to antitubulin agents: microtubule dynamics, drug transport, and cell death. J Clin Oncol 17:1061-1070

120. Harrington AW, Ginty DD (2013) Long-distance retrograde neurotrophic factor signalling in neurons. Nat Rev Neurosci 14:177-187

121. Moughamian AJ, Osborn GE, Lazarus JE, Maday S, Holzbaur ELF (2013) Ordered recruitment of dynactin to the microtubule plus-end is required for efficient initiation of retrograde axonal transport. J Neurosci 33:13190-13203

122. Kochl R, Hu XW, Chan EY, Tooze SA (2006) Microtubules facilitate autophagosome formation and fusion of autophagosomes with endosomes. Traffic 7:129-145

123. Arduino DM, Esteves AR, Cortes L, Silva DF, Patel B, Grazina M, Swerdlow RH, Oliveira CR, Cardoso SM (2012) Mitochondrial metabolism in Parkinson's disease impairs quality control autophagy by hampering microtubule-dependent traffic. Hum Mol Genet 21:4680-4702

124. Baker M, Mackenzie IR, Pickering-Brown SM, Gass J, Rademakers R, Lindholm C, Snowden J, Adamson J, Sadovnick AD, Rollinson S, Cannon A, Dwosh E, Neary D, Melquist S, Richardson A, Dickson D, Berger Z, Eriksen J, Robinson T, Zehr C, Dickey CA, Crook R, McGowan E, Mann D, Boeve B, Feldman H, Hutton M (2006) Mutations in progranulin cause tau-negative frontotemporal dementia linked to chromosome 17. Nature 442:916-919

125. Stanford PM, Halliday GM, Brooks WS, Kwok JB, Storey CE, Creasey H, Morris JG, Fulham MJ, Schofield PR (2000) Progressive supranuclear palsy pathology caused by a novel silent mutation in exon 10 of the tau gene: expansion of the disease phenotype caused by tau gene mutations. Brain 123(Pt 5):880-893

126. Kanaan NM, Cox K, Alvarez VE, Stein TD, Poncil S, McKee AC (2016) Characterization of early pathological tau conformations and phosphorylation in chronic traumatic encephalopathy. J Neuropathol Exp Neurol 7:19-34

127. Grossman M, Elman L, McCluskey L, McMillan CT, Boller A, Powers J, Rascovsky K, Hu W, Shaw L, Irwin DJ, Lee VMY, Trojanowski JQ (2014) Phosphorylated tau as a candidate biomarker for amyotrophic lateral sclerosis. JAMA Neurol 71:442-448

128. Lei P, Ayton S, Finkelstein DI, Adlard PA, Masters CL, Bush AI (2010) Tau protein: relevance to Parkinson's disease. Int J Biochem Cell Biol 42:1775-1778

129. Irwin DJ, Lee VM, Trojanowski JQ (2013) Parkinson's disease dementia: convergence of alpha-synuclein, tau and amyloid-beta pathologies. Nat Rev Neurosci 14:626-636

130. Neve RL, Harris P, Kosik KS, Kurnit DM, Donlon TA (1986) Identification of Cdna clones for the human microtubule-associated protein tau and chromosomal localization of the genes for tau and microtubule-associated protein-2. Mol Brain Res $1: 271-280$ 
131. Mandelkow EM, Mandelkow E (2012) Biochemistry and cell biology of tau protein in neurofibrillary degeneration. Cold Spring Harb Perspect Med 2:a006247

132. Lee G, Leugers CJ (2012) Tau and tauopathies. Prog Mol Biol Transl Sci 107:263-293

133. Buee L, Bussiere T, Buee-Scherrer V, Delacourte A, Hof PR (2000) Tau protein isoforms, phosphorylation and role in neurodegenerative disorders. Brain Res Brain Res Rev 33:95-130

134. Chen J, Kanai Y, Cowan NJ, Hirokawa N (1992) Projection domains of MAP2 and tau determine spacings between microtubules in dendrites and axons. Nature 360:674-677

135. Elie A, Prezel E, Guerin C, Denarier E, Ramirez-Rios S, Serre L, Andrieux A, Fourest-Lieuvin A, Blanchoin L, Arnal I (2015) Tau co-organizes dynamic microtubule and actin networks. Sci Rep 5:9964

136. Trinczek B, Biernat J, Baumann K, Mandelkow EM, Mandelkow E (1995) Domains of tau protein, differential phosphorylation, and dynamic instability of microtubules. Mol Biol Cell 6:1887-1902

137. Bramblett GT, Goedert M, Jakes R, Merrick SE, Trojanowski JQ, Lee VM (1993) Abnormal tau phosphorylation at Ser396 in Alzheimer's disease recapitulates development and contributes to reduced microtubule binding. Neuron 10:1089-1099

138. Cho JH, Johnson GV (2004) Primed phosphorylation of tau at Thr231 by glycogen synthase kinase 3beta (GSK3beta) plays a critical role in regulating tau's ability to bind and stabilize microtubules. J Neurochem 88:349-358

139. Zhang B, Maiti A, Shively S, Lakhani F, McDonald-Jones G, Bruce J, Lee EB, Xie SX, Joyce S, Li C, Toleikis PM, Lee VM, Trojanowski JQ (2005) Microtubule-binding drugs offset tau sequestration by stabilizing microtubules and reversing fast axonal transport deficits in a tauopathy model. Proc Natl Acad Sci U S A 102:227-231

140. Vossel KA, Zhang K, Brodbeck J, Daub AC, Sharma P, Finkbeiner S, Cui B, Mucke L (2010) Tau reduction prevents Abetainduced defects in axonal transport. Science 330:198

141. Matenia D, Mandelkow EM (2009) The tau of MARK: a polarized view of the cytoskeleton. Trends Biochem Sci 34:332-342

142. Cohen TJ, Guo JL, Hurtado DE, Kwong LK, Mills IP, Trojanowski JQ, Lee VM (2011) The acetylation of tau inhibits its function and promotes pathological tau aggregation. Nat Commun $2: 252$

143. Cook C, Carlomagno Y, Gendron TF, Dunmore J, Scheffel K, Stetler C, Davis M, Dickson D, Jarpe M, DeTure M, Petrucelli L (2014) Acetylation of the KXGS motifs in tau is a critical determinant in modulation of tau aggregation and clearance. Hum Mol Genet 23:104-116

144. Gotz J, Ittner LM (2008) Animal models of Alzheimer's disease and frontotemporal dementia. Nat Rev Neurosci 9:532-544

145. Denk F, Wade-Martins R (2009) Knock-out and transgenic mouse models of tauopathies. Neurobiol Aging 30:1-13

146. Kosik KS, Orecchio LD, Bakalis S, Neve RL (1989) Developmentally regulated expression of specific tau sequences. Neuron 2:1389-1397

147. Shin RW, Iwaki T, Kitamoto T, Sato Y, Tateishi J (1992) Massive accumulation of modified-tau and severe depletion of normal-tau characterize the cerebral-cortex and white matter of Alzheimers-disease-demonstration using the hydrated autoclaving method. Am J Pathol 140:937-945

148. Goedert M (2005) Tau gene mutations and their effects. Mov Disord 20(Suppl 12):S45-S52

149. Cookson MR (2005) The biochemistry of Parkinson's disease. Annu Rev Biochem 74:29-52

150. Esposito A, Dohm CP, Kermer P, Bahr M, Wouters FS (2007) alpha-Synuclein and its disease-related mutants interact differentially with the microtubule protein tau and associate with the actin cytoskeleton. Neurobiol Dis 26:521-531

151. Jensen PH, Hager H, Nielsen MS, Hojrup P, Gliemann J, Jakes $\mathrm{R}$ (1999) alpha-synuclein binds to Tau and stimulates the protein kinase A-catalyzed tau phosphorylation of serine residues 262 and 356. J Biol Chem 274:25481-25489

152. Duka T, Duka V, Joyce JN, Sidhu A (2009) alpha-Synuclein contributes to GSK-3 beta-catalyzed Tau phosphorylation in Parkinson's disease models. FASEB J 23:2820-2830

153. Tobin JE, Latourelle JC, Lew MF, Klein C, Suchowersky O, Shill HA, Golbe LI, Mark MH, Growdon JH, Wooten GF, Racette BA, Perlmutter JS, Watts R, Guttman M, Baker KB, Goldwurm S, Pezzoli G, Singer C, Saint-Hilaire MH, Hendricks AE, Williamson S, Nagle MW, Wilk JB, Massood T, Laramie JM, DeStefano AL, Litvan I, Nicholson G, Corbett A, Isaacson S, Burn DJ, Chinnery PF, Pramstaller PP, Sherman S, Al-hinti J, Drasby E, Nance M, Moller AT, Ostergaard K, Roxburgh R, Snow B, Slevin JT, Cambi F, Gusella JF, Myers RH (2008) Haplotypes and gene expression implicate the MAPT region for Parkinson disease: the GenePD Study. Neurology 71:28-34

154. Simon-Sanchez J, Schulte C, Bras JM, Sharma M, Gibbs JR, Berg D, Paisan-Ruiz C, Lichtner P, Scholz SW, Hernandez DG, Kruger R, Federoff M, Klein C, Goate A, Perlmutter J, Bonin M, Nalls MA, Illig T, Gieger C, Houlden H, Steffens M, Okun MS, Racette BA, Cookson MR, Foote KD, Fernandez HH, Traynor BJ, Schreiber S, Arepalli S, Zonozi R, Gwinn K, van der Brug M, Lopez G, Chanock SJ, Schatzkin A, Park Y, Hollenbeck A, Gao JJ, Huang XM, Wood NW, Lorenz D, Deuschl G, Chen HL, Riess O, Hardy JA, Singleton AB, Gasser T (2009) Genomewide association study reveals genetic risk underlying Parkinson's disease. Nat Genet 41:1308-1312

155. Zabetian CP, Hutter CM, Factor SA, Nutt JG, Higgins DS, Griffith A, Roberts JW, Leis BC, Kay DM, Yearout D, Montimurro JS, Edwards KL, Samii A, Payami H (2007) Association analysis of MAPT H1 haplotype and subhaplotypes in Parkinson's disease. Ann Neurol 62:137-144

156. Ren Y, Zhao J, Feng J (2003) Parkin binds to alpha/beta tubulin and increases their ubiquitination and degradation. $J$ Neurosci 23:3316-3324

157. Bonifati V (2014) Genetics of Parkinson's disease-state of the art, 2013. Parkinsonism Relat Disord 20(Suppl 1):S23-S28

158. Shimura H, Hattori N, Kubo S, Mizuno Y, Asakawa S, Minoshima S, Shimizu N, Iwai K, Chiba T, Tanaka K, Suzuki T (2000) Familial Parkinson disease gene product, parkin, is a ubiquitin-protein ligase. Nat Genet 25:302-305

159. Kitada T, Asakawa S, Hattori N, Matsumine H, Yamamura Y, Minoshima S, Yokochi M, Mizuno Y, Shimizu N (1998) Mutations in the parkin gene cause autosomal recessive juvenile parkinsonism. Nature 392:605-608

160. Wauer T, Komander D (2013) Structure of the human Parkin ligase domain in an autoinhibited state. EMBO J 32:2099-2112

161. Ren Y, Jiang H, Yang F, Nakaso K, Feng J (2009) Parkin protects dopaminergic neurons against microtubule-depolymerizing toxins by attenuating microtubule-associated protein kinase activation. J Biol Chem 284:4009-4017

162. Ren Y, Liu W, Jiang H, Jiang Q, Feng J (2005) Selective vulnerability of dopaminergic neurons to microtubule depolymerization. J Biol Chem 280:34105-34112

163. Wang X, Winter D, Ashrafi G, Schlehe J, Wong YL, Selkoe D, Rice S, Steen J, LaVoie MJ, Schwarz TL (2011) PINK1 and Parkin target Miro for phosphorylation and degradation to arrest mitochondrial motility. Cell 147:893-906

164. Narendra D, Tanaka A, Suen DF, Youle RJ (2008) Parkin is recruited selectively to impaired mitochondria and promotes their autophagy. J Cell Biol 183:795-803 
165. Kane LA, Youle RJ (2011) PINK1 and Parkin flag Miro to direct mitochondrial traffic. Cell 147:721-723

166. Itoh K, Nakamura K, Iijima M, Sesaki H (2013) Mitochondrial dynamics in neurodegeneration. Trends Cell Biol 23:64-71

167. Guo XF, Macleod GT, Wellington A, Hu F, Panchumarthi S, Schoenfield M, Marin L, Charlton MP, Atwood HL, Zinsmaier KE (2005) The GTPase dMiro is required for axonal transport of mitochondria to Drosophila synapses. Neuron 47:379-393

168. Glater EE, Megeath LJ, Stowers RS, Schwarz TL (2006) Axonal transport of mitochondria requires milton to recruit kinesin heavy chain and is light chain independent. J Cell Biol 173:545-557

169. Stowers RS, Megeath LJ, Gorska-Andrzejak J, Meinertzhagen IA, Schwarz TL (2002) Axonal transport of mitochondria to synapses depends on milton, a novel Drosophila protein. Neuron 36:1063-1077

170. Vives-Bauza C, Zhou C, Huang Y, Cui M, de Vries RL, Kim J, May J, Tocilescu MA, Liu W, Ko HS, Magrane J, Moore DJ, Dawson VL, Grailhe R, Dawson TM, Li C, Tieu K, Przedborski S (2010) PINK1-dependent recruitment of Parkin to mitochondria in mitophagy. Proc Natl Acad Sci U S A 107:378-383

171. Matsuda N, Sato S, Shiba K, Okatsu K, Saisho K, Gautier CA, Sou YS, Saiki S, Kawajiri S, Sato F, Kimura M, Komatsu M, Hattori N, Tanaka K (2010) PINK1 stabilized by mitochondrial depolarization recruits Parkin to damaged mitochondria and activates latent Parkin for mitophagy. J Cell Biol 189:211-221

172. Liu S, Sawada T, Lee S, Yu W, Silverio G, Alapatt P, Millan I, Shen A, Saxton W, Kanao T, Takahashi R, Hattori N, Imai Y, Lu B (2012) Parkinson's disease-associated kinase PINK1 regulates Miro protein level and axonal transport of mitochondria. PLoS Genet 8:e1002537

173. Miller KE, Sheetz MP (2004) Axonal mitochondrial transport and potential are correlated. J Cell Sci 117:2791-2804

174. Narendra DP, Jin SM, Tanaka A, Suen DF, Gautier CA, Shen J, Cookson MR, Youle RJ (2010) PINK1 is selectively stabilized on impaired mitochondria to activate Parkin. PLoS Biol 8:e1000298

175. Lin W, Kang UJ (2008) Characterization of PINK1 processing, stability, and subcellular localization. J Neurochem 106:464-474

176. Kazlauskaite A, Muqit MMK (2015) PINK1 and Parkin mitochondrial interplay between phosphorylation and ubiquitylation in Parkinson's disease. FEBS J 282:215-223

177. Matenia D, Hempp C, Timm T, Eikhof A, Mandelkow EM (2012) Microtubule affinity-regulating kinase 2 (MARK2) turns on phosphatase and tensin homolog (PTEN)-induced kinase 1 (PINK1) at Thr-313, a mutation site in Parkinson disease: effects on mitochondrial transport. J Biol Chem 287:8174-8186

178. Matenia D, Mandelkow EM (2014) Emerging modes of PINK1 signaling: another task for MARK2. Front Mol Neurosci 7:37

179. Biernat J, Wu YZ, Timm T, Zheng-Fischhofer Q, Mandelkow E, Meijer L, Mandelkow EM (2002) Protein kinase MARK/PAR-1 is required for neurite outgrowth and establishment of neuronal polarity. Mol Biol Cell 13:4013-4028

180. Dagda RK, Pien I, Wang R, Zhu J, Wang KZ, Callio J, Banerjee TD, Dagda RY, Chu CT (2014) Beyond the mitochondrion: cytosolic PINK1 remodels dendrites through protein kinase A. J Neurochem 128:864-877

181. Berwick DC, Harvey K (2013) LRRK2: an eminence grise of Wnt-mediated neurogenesis? Front Cell Neurosci 7:82

182. Zimprich A, Biskup S, Leitner P, Lichtner P, Farrer M, Lincoln S, Kachergus J, Hulihan M, Uitti RJ, Calne DB, Stoessl AJ, Pfeiffer RF, Patenge N, Carbajal IC, Vieregge P, Asmus F, Muller-Myhsok B, Dickson DW, Meitinger T, Strom TM, Wszolek ZK, Gasser T (2004) Mutations in LRRK2 cause autosomal-dominant parkinsonism with pleomorphic pathology. Neuron 44:601-607

183. Paisan-Ruiz C, Jain S, Evans EW, Gilks WP, Simon J, van der Brug M, Lopez de Munain A, Aparicio S, Gil AM, Khan N, Johnson J, Martinez JR, Nicholl D, Carrera IM, Pena AS, de Silva R, Lees A, Marti-Masso JF, Perez-Tur J, Wood NW, Singleton AB (2004) Cloning of the gene containing mutations that cause PARK8-linked Parkinson's disease. Neuron 44:595-600

184. Kawakami F, Yabata T, Ohta E, Maekawa T, Shimada N, Suzuki M, Maruyama H, Ichikawa T, Obata F (2012) LRRK2 phosphorylates tubulin-associated tau but not the free molecule: LRRK2-mediated regulation of the tau-tubulin association and neurite outgrowth. PLoS One 7:e30834

185. Parisiadou L, Xie C, Cho HJ, Lin X, Gu XL, Long CX, Lobbestael E, Baekelandt V, Taymans JM, Sun L, Cai H (2009) Phosphorylation of ezrin/radixin/moesin proteins by LRRK2 promotes the rearrangement of actin cytoskeleton in neuronal morphogenesis. J Neurosci 29:13971-13980

186. Gloeckner CJ, Kinkl N, Schumacher A, Braun RJ, O’Neill E, Meitinger T, Kolch W, Prokisch H, Ueffing M (2006) The Parkinson disease causing LRRK2 mutation I2020T is associated with increased kinase activity. Hum Mol Genet 15:223-232

187. Sancho RM, Law BM, Harvey K (2009) Mutations in the LRRK2 Roc-COR tandem domain link Parkinson's disease to Wnt signalling pathways. Hum Mol Genet 18:3955-3968

188. Habig K, Gellhaar S, Heim B, Djuric V, Giesert F, Wurst W, Walter C, Hentrich T, Riess O, Bonin M (2013) LRRK2 guides the actin cytoskeleton at growth cones together with ARHGEF7 and Tropomyosin 4. Biochim Biophys Acta 1832:2352-2367

189. Gillardon F (2009) Leucine-rich repeat kinase 2 phosphorylates brain tubulin-beta isoforms and modulates microtubule stability-a point of convergence in parkinsonian neurodegeneration? J Neurochem 110:1514-1522

190. Esteves AR, G-Fernandes M, Santos D, Januario C, Cardoso SM (2015) The upshot of LRRK2 inhibition to Parkinson's disease paradigm. Mol Neurobiol 52:1804-1820

191. Esteves AR, Cardoso SM (2016) LRRK2 at the crossroad between autophagy and microtubule trafficking: insights into Parkinson's disease. Neuroscientist (Epub ahead of print)

192. Khan NL, Jain S, Lynch JM, Pavese N, Abou-Sleiman P, Holton JL, Healy DG, Gilks WP, Sweeney MG, Ganguly M, Gibbons V, Gandhi S, Vaughan J, Eunson LH, Katzenschlager R, Gayton J, Lennox G, Revesz T, Nicholl D, Bhatia KP, Quinn N, Brooks D, Lees AJ, Davis MB, Piccini P, Singleton AB, Wood NW (2005) Mutations in the gene LRRK2 encoding dardarin (PARK8) cause familial Parkinson's disease: clinical, pathological, olfactory and functional imaging and genetic data. Brain 128:2786-2796

193. Rajput A, Dickson DW, Robinson CA, Ross OA, Dachsel JC, Lincoln SJ, Cobb SA, Rajput ML, Farrer MJ (2006) Parkinsonism, Lrrk2 G2019S, and tau neuropathology. Neurology 67:1506-1508

194. Ujiie S, Hatano T, Kubo S, Imai S, Sato S, Uchihara T, Yagishita S, Hasegawa K, Kowa H, Sakai F, Hattori N (2012) LRRK2 I2020T mutation is associated with tau pathology. Parkinsonism Relat Disord 18:819-823

195. Li Y, Liu W, Oo TF, Wang L, Tang Y, Jackson-Lewis V, Zhou C, Geghman K, Bogdanov M, Przedborski S, Beal MF, Burke RE, Li C (2009) Mutant LRRK2(R1441G) BAC transgenic mice recapitulate cardinal features of Parkinson's disease. Nat Neurosci 12:826-828

196. Melrose HL, Dachsel JC, Behrouz B, Lincoln SJ, Yue M, Hinkle KM, Kent CB, Korvatska E, Taylor JP, Witten L, Liang YQ, Beevers JE, Boules M, Dugger BN, Serna VA, Gaukhman A, Yu $\mathrm{X}$, Castanedes-Casey M, Braithwaite AT, Ogholikhan S, Yu N, 
Bass D, Tyndall G, Schellenberg GD, Dickson DW, Janus C, Farrer MJ (2010) Impaired dopaminergic neurotransmission and microtubule-associated protein tau alterations in human LRRK2 transgenic mice. Neurobiol Dis 40:503-517

197. Bailey RM, Covy JP, Melrose HL, Rousseau L, Watkinson R, Knight J, Miles S, Farrer MJ, Dickson DW, Giasson BI, Lewis J (2013) LRRK2 phosphorylates novel tau epitopes and promotes tauopathy. Acta Neuropathol 126:809-827

198. Lin CH, Tsai PI, Wu RM, Chien CT (2010) LRRK2 G2019S mutation induces dendrite degeneration through mislocalization and phosphorylation of tau by recruiting autoactivated GSK3ss. J Neurosci 30:13138-13149

199. Kawakami F, Shimada N, Ohta E, Kagiya G, Kawashima R, Maekawa T, Maruyama H, Ichikawa T (2014) Leucine-rich repeat kinase 2 regulates tau phosphorylation through direct activation of glycogen synthase kinase-3beta. FEBS J 281:3-13

200. Polymeropoulos MH, Lavedan C, Leroy E, Ide SE, Dehejia A, Dutra A, Pike B, Root H, Rubenstein J, Boyer R, Stenroos ES, Chandrasekharappa S, Athanassiadou A, Papapetropoulos T, Johnson WG, Lazzarini AM, Duvoisin RC, Di Iorio G, Golbe LI, Nussbaum RL (1997) Mutation in the alpha-synuclein gene identified in families with Parkinson's disease. Science 276:2045-2047

201. Singleton AB, Farrer M, Johnson J, Singleton A, Hague S, Kachergus J, Hulihan M, Peuralinna T, Dutra A, Nussbaum R, Lincoln S, Crawley A, Hanson M, Maraganore D, Adler C, Cookson MR, Muenter M, Baptista M, Miller D, Blancato J, Hardy J, Gwinn-Hardy K (2003) alpha-Synuclein locus triplication causes Parkinson's disease. Science 302:841

202. Spillantini MG, Schmidt ML, Lee VM, Trojanowski JQ, Jakes R, Goedert M (1997) Alpha-synuclein in Lewy bodies. Nature 388:839-840

203. Alim MA, Hossain MS, Arima K, Takeda K, Izumiyama Y, Nakamura M, Kaji H, Shinoda T, Hisanaga S, Ueda K (2002) Tubulin seeds alpha-synuclein fibril formation. J Biol Chem 277:2112-2117

204. Ishizawa T, Mattila P, Davies P, Wang D, Dickson DW (2003) Colocalization of tau and alpha-synuclein epitopes in Lewy bodies. J Neuropathol Exp Neurol 62:389-397

205. Taymans JM, Cookson MR (2010) Mechanisms in dominant parkinsonism: the toxic triangle of LRRK2, alpha-synuclein, and tau. Bioessays 32:227-235

206. Greggio E, Jain S, Kingsbury A, Bandopadhyay R, Lewis P, Kaganovich A, van der Brug MP, Beilina A, Blackinton J, Thomas KJ, Ahmad R, Miller DW, Kesavapany S, Singleton A, Lees A, Harvey RJ, Harvey K, Cookson MR (2006) Kinase activity is required for the toxic effects of mutant LRRK2/dardarin. Neurobiol Dis 23:329-341

207. Qing H, Wong W, McGeer EG, McGeer PL (2009) Lrrk2 phosphorylates alpha synuclein at serine 129: Parkinson disease implications. Biochem Bioph Res Commun 387:149-152

208. Abeliovich A, Schmitz Y, Farinas I, Choi-Lundberg D, Ho WH, Castillo PE, Shinsky N, Verdugo JM, Armanini M, Ryan A, Hynes M, Phillips H, Sulzer D, Rosenthal A (2000) Mice lacking alpha-synuclein display functional deficits in the nigrostriatal dopamine system. Neuron 25:239-252

209. Chandra S, Fornai F, Kwon HB, Yazdani U, Atasoy D, Liu X, Hammer RE, Battaglia G, German DC, Castillo PE, Sudhof TC (2004) Double-knockout mice for alpha- and beta-synucleins: effect on synaptic functions. Proc Natl Acad Sci U S A 101:14966-14971

210. Lee HJ, Khoshaghideh F, Lee S, Lee SJ (2006) Impairment of microtubule-dependent trafficking by overexpression of alphasynuclein. Eur J Neurosci 24:3153-3162

211. Prots I, Veber V, Brey S, Campioni S, Buder K, Riek R, Bohm KJ, Winner B (2013) alpha-Synuclein oligomers impair neuronal microtubule-kinesin interplay. $\mathrm{J}$ Biol Chem 288:21742-21754

212. Gassowska M, Czapski GA, Pajak B, Cieslik M, Lenkiewicz AM, Adamczyk A (2014) Extracellular alpha-synuclein leads to microtubule destabilization via GSK-3beta-dependent Tau phosphorylation in PC12 cells. PLoS One 9:e94259

213. Liu G, Wang P, Li X, Li Y, Xu S, Ueda K, Chan P, Yu S (2013) Alpha-synuclein promotes early neurite outgrowth in cultured primary neurons. J Neural Transm (Vienna) 120:1331-1343

214. Koch JC, Bitow F, Haack J, d'Hedouville Z, Zhang JN, Tonges L, Michel U, Oliveira LM, Jovin TM, Liman J, Tatenhorst L, Bahr M, Lingor P (2015) Alpha-Synuclein affects neurite morphology, autophagy, vesicle transport and axonal degeneration in CNS neurons. Cell Death Dis 6:e1811

215. Stefanis L (2012) alpha-Synuclein in Parkinson's disease. Cold Spring Harb Perspect Med 2:a009399

216. Winner B, Jappelli R, Maji SK, Desplats PA, Boyer L, Aigner S, Hetzer C, Loher T, Vilar M, Campionic S, Tzitzilonis C, Soragni A, Jessberger S, Mira H, Consiglio A, Pham E, Masliah E, Gage FH, Riek R (2011) In vivo demonstration that alpha-synuclein oligomers are toxic. Proc Natl Acad Sci USA 108:4194-4199

217. Esteves AR, Arduino DM, Swerdlow RH, Oliveira CR, Cardoso SM (2010) Microtubule depolymerization potentiates alphasynuclein oligomerization. Front Aging Neurosci 1:5

218. Chung CY, Koprich JB, Siddiqi H, Isacson O (2009) Dynamic changes in presynaptic and axonal transport proteins combined with striatal neuroinflammation precede dopaminergic neuronal loss in a rat model of AAV alpha-synucleinopathy. J Neurosci 29:3365-3373

219. Giasson BI, Forman MS, Higuchi M, Golbe LI, Graves CL, Kotzbauer PT, Trojanowski JQ, Lee VMY (2003) Initiation and synergistic fibrillization of tau and alpha-synuclein. Science 300:636-640

220. Canet-Aviles RM, Wilson MA, Miller DW, Ahmad R, McLendon C, Bandyopadhyay S, Baptista MJ, Ringe D, Petsko GA, Cookson MR (2004) The Parkinson's disease protein DJ-1 is neuroprotective due to cysteine-sulfinic acid-driven mitochondrial localization. Proc Natl Acad Sci U S A 101:9103-9108

221. Thomas KJ, McCoy MK, Blackinton J, Beilina A, van der Brug M, Sandebring A, Miller D, Maric D, Cedazo-Minguez A, Cookson MR (2011) DJ-1 acts in parallel to the PINK1/parkin pathway to control mitochondrial function and autophagy. Hum Mol Genet 20:40-50

222. Sheng $\mathrm{C}$, Heng X, Zhang G, Xiong R, Li H, Zhang S, Chen S (2013) DJ-1 deficiency perturbs microtubule dynamics and impairs striatal neurite outgrowth. Neurobiol Aging 34:489-498

223. Altmann KH (2001) Microtubule-stabilizing agents: a growing class of important anticancer drugs. Curr Opin Chem Biol 5:424-431

224. Zhao Y, Fang WS, Pors K (2009) Microtubule stabilising agents for cancer chemotherapy. Expert Opin Ther Pat 19:607-622

225. Zhao Y, Mu X, Du G (2016) Microtubule-stabilizing agents: new drug discovery and cancer therapy. Pharmacol Ther 162:134-143

226. Ballatore C, Brunden KR, Huryn DM, Trojanowski JQ, Lee VM, Smith AB 3rd (2012) Microtubule stabilizing agents as potential treatment for Alzheimer's disease and related neurodegenerative tauopathies. J Med Chem 55:8979-8996

227. Brunden KR, Trojanowski JQ, Smith AB 3rd, Lee VM, Ballatore C (2014) Microtubule-stabilizing agents as potential therapeutics for neurodegenerative disease. Bioorg Med Chem 22:5040-5049

228. Wani MC, Taylor HL, Wall ME, Coggon P, McPhail AT (1971) Plant antitumor agents. VI. The isolation and structure of taxol, a 
novel antileukemic and antitumor agent from Taxus brevifolia. J Am Chem Soc 93:2325-2327

229. Prota AE, Bargsten K, Zurwerra D, Field JJ, Diaz JF, Altmann KH, Steinmetz MO (2013) Molecular mechanism of action of microtubule-stabilizing anticancer agents. Science 339:587-590

230. Schiff PB, Fant J, Horwitz SB (1979) Promotion of microtubule assembly in vitro by taxol. Nature 277:665-667

231. Parness J, Horwitz SB (1981) Taxol binds to polymerized tubulin in vitro. J Cell Biol 91:479-487

232. Wilson L, Miller HP, Farrell KW, Snyder KB, Thompson WC, Purich DL (1985) Taxol stabilization of microtubules in vitro: dynamics of tubulin addition and loss at opposite microtubule ends. Biochemistry 24:5254-5262

233. Jordan MA, Toso RJ, Thrower D, Wilson L (1993) Mechanism of mitotic block and inhibition of cell-proliferation by taxol at low concentrations. Proc Natl Acad Sci U S A 90:9552-9556

234. Piperno G, LeDizet M, Chang XJ (1987) Microtubules containing acetylated alpha-tubulin in mammalian cells in culture. J Cell Biol 104:289-302

235. Amos LA, Lowe J (1999) How Taxol stabilises microtubule structure. Chem Biol 6:R65-R69

236. Amos LA (2004) Microtubule structure and its stabilisation. Org Biomol Chem 2:2153-2160

237. Field JJ, Pera B, Calvo E, Canales A, Zurwerra D, Trigili C, Rodriguez-Salarichs J, Matesanz R, Kanakkanthara A, Wakefield SJ, Singh AJ, Jimenez-Barbero J, Northcote P, Miller JH, Lopez JA, Hamel E, Barasoain I, Altmann KH, Diaz JF (2012) Zampanolide, a potent new microtubule-stabilizing agent, covalently reacts with the taxane luminal site in tubulin alpha, beta-heterodimers and microtubules. Chem Biol 19:686-698

238. Karbowski M, Spodnik JH, Teranishi M, Wozniak M, Nishizawa Y, Usukura J, Wakabayashi T (2001) Opposite effects of microtubule-stabilizing and microtubule-destabilizing drugs on biogenesis of mitochondria in mammalian cells. J Cell Sci 114:281-291

239. Samsonov A, Yu JZ, Rasenick M, Popov SV (2004) Tau interaction with microtubules in vivo. J Cell Sci 117:6129-6141

240. Brunden KR, Yao Y, Potuzak JS, Ferrer NI, Ballatore C, James MJ, Hogan AM, Trojanowski JQ, Smith AB 3rd, Lee VM (2011) The characterization of microtubule-stabilizing drugs as possible therapeutic agents for Alzheimer's disease and related tauopathies. Pharmacol Res 63:341-351

241. Bouchet BP, Galmarini CM (2010) Cabazitaxel, a new taxane with favorable properties. Drugs Today (Barc) 46:735-742

242. Laccabue D, Tortoreto M, Veneroni S, Perego P, Scanziani E, Zucchetti M, Zaffaroni M, D'Incalci M, Bombardelli E, Zunino F, Pratesi G (2001) A novel taxane active against an orthotopically growing human glioma xenograft. Cancer 92:3085-3092

243. Fitzgerald DP, Emerson DL, Qian Y, Anwar T, Liewehr DJ, Steinberg SM, Silberman S, Palmieri D, Steeg PS (2012) TPI287 , a new taxane family member, reduces the brain metastatic colonization of breast cancer cells. Mol Cancer Ther 11:1959-1967

244. Ballatore C, Zhang B, Trojanowski JQ, Lee VM, Smith AB 3rd (2008) In situ blood-brain barrier permeability of a C-10 paclitaxel carbamate. Bioorg Med Chem Lett 18:6119-6121

245. Rice A, Michaelis ML, Georg G, Liu Y, Turunen B, Audus KL (2003) Overcoming the blood-brain barrier to taxane delivery for neurodegenerative diseases and brain tumors. J Mol Neurosci 20:339-343

246. Kurzrock R, Gabrail N, Chandhasin C, Moulder S, Smith C, Brenner A, Sankhala K, Mita A, Elian K, Bouchard D, Sarantopoulos J (2012) Safety, pharmacokinetics, and activity of GRN1005, a novel conjugate of angiopep-2, a peptide facilitating brain penetration, and paclitaxel, in patients with advanced solid tumors. Mol Cancer Ther 11:308-316

247. Fanara P, Banerjee J, Hueck RV, Harper MR, Awada M, Turner H, Husted KH, Brandt R, Hellerstein MK (2007) Stabilization of hyperdynamic microtubules is neuroprotective in amyotrophic lateral sclerosis. J Biol Chem 282:23465-23472

248. Brunden KR, Zhang B, Carroll J, Yao Y, Potuzak JS, Hogan AM, Iba M, James MJ, Xie SX, Ballatore C, Smith AB 3rd, Lee VM, Trojanowski JQ (2010) Epothilone D improves microtubule density, axonal integrity, and cognition in a transgenic mouse model of tauopathy. J Neurosci 30:13861-13866

249. Zhang B, Carroll J, Trojanowski JQ, Yao Y, Iba M, Potuzak JS, Hogan AM, Xie SX, Ballatore C, Smith AB 3rd, Lee VM, Brunden KR (2012) The microtubule-stabilizing agent, epothilone $\mathrm{D}$, reduces axonal dysfunction, neurotoxicity, cognitive deficits, and Alzheimer-like pathology in an interventional study with aged tau transgenic mice. J Neurosci 32:3601-3611

250. Brizuela M, Blizzard CA, Chuckowree JA, Dawkins E, Gasperini RJ, Young KM, Dickson TC (2015) The microtubulestabilizing drug Epothilone D increases axonal sprouting following transection injury in vitro. Mol Cell Neurosci 66:129-140

251. Empey DW, Laitinen LA, Young GA, Bye CE, Hughes DT (1979) Comparison of the antitussive effects of codeine phosphate $20 \mathrm{mg}$, dextromethorphan $30 \mathrm{mg}$ and noscapine $30 \mathrm{mg}$ using citric acid-induced cough in normal subjects. Eur J Clin Pharmacol 16:393-397

252. Landen JW, Lang R, McMahon SJ, Rusan NM, Yvon AM, Adams AW, Sorcinelli MD, Campbell R, Bonaccorsi P, Ansel JC, Archer DR, Wadsworth P, Armstrong CA, Joshi HC (2002) Noscapine alters microtubule dynamics in living cells and inhibits the progression of melanoma. Cancer Res 62:4109-4114

253. Ye KQ, Ke Y, Keshava N, Shanks J, Kapp JA, Tekmal RR, Petros J, Joshi HC (1998) Opium alkaloid noscapine is an antitumor agent that arrests metaphase and induces apoptosis in dividing cells. Proc Natl Acad Sci U S A 95:1601-1606

254. Zhou J, Panda D, Landen JW, Wilson L, Joshi HC (2002) Minor alteration of microtubule dynamics causes loss of tension across kinetochore pairs and activates the spindle checkpoint. J Biol Chem 277:17200-17208

255. Bennani YL, Gu W, Canales A, Diaz FJ, Eustace BK, Hoover RR, Jimenez-Barbero J, Nezami A, Wang T (2012) Tubulin binding, protein-bound conformation in solution, and antimitotic cellular profiling of noscapine and its derivatives. J Med Chem 55:1920-1925

256. Fanara P, Wong PY, Husted KH, Liu S, Liu VM, Kohlstaedt LA, Riiff T, Protasio JC, Boban D, Killion S, Killian M, Epling L, Sinclair E, Peterson J, Price RW, Cabin DE, Nussbaum RL, Bruhmann J, Brandt R, Christine CW, Aminoff MJ, Hellerstein MK (2012) Cerebrospinal fluid-based kinetic biomarkers of axonal transport in monitoring neurodegeneration. J Clin Invest 122:3159-3169

257. Gold WA, Lacina TA, Cantrill LC, Christodoulou J (2015) $\mathrm{MeCP} 2$ deficiency is associated with reduced levels of tubulin acetylation and can be restored using HDAC6 inhibitors. J Mol Med (Berl) 93:63-72

258. Pinho BR, Reis SD, Guedes-Dias P, Leitao-Rocha A, Quintas C, Valentao P, Andrade PB, Santos MM, Oliveira JM (2016) Pharmacological modulation of HDAC1 and HDAC6 in vivo in a zebrafish model: therapeutic implications for Parkinson's disease. Pharmacol Res 103:328-339

259. Taes I, Timmers M, Hersmus N, Bento-Abreu A, Van Den Bosch L, Van Damme P, Auwerx J, Robberecht W (2013) Hdac6 deletion delays disease progression in the SOD1G93A mouse model of ALS. Hum Mol Genet 22:1783-1790 
260. Govindarajan N, Rao P, Burkhardt S, Sananbenesi F, Schluter OM, Bradke F, Lu J, Fischer A (2013) Reducing HDAC6 ameliorates cognitive deficits in a mouse model for Alzheimer's disease. EMBO Mol Med 5:52-63

261. d'Ydewalle C, Krishnan J, Chiheb DM, Van Damme P, Irobi J, Kozikowski AP, Vanden Berghe P, Timmerman V, Robberecht W, Van Den Bosch L (2011) HDAC6 inhibitors reverse axonal loss in a mouse model of mutant HSPB1-induced CharcotMarie-Tooth disease. Nat Med 17:968-974

262. Siegel GJ, Chauhan NB (2000) Neurotrophic factors in Alzheimer's and Parkinson's disease brain. Brain Res Brain Res Rev 33:199-227

263. Hegarty SV, O'Keeffe GW, Sullivan AM (2014) Neurotrophic factors: from neurodevelopmental regulators to novel therapies for Parkinson's disease. Neural Regen Res 9:1708-1711

264. Sendtner M, Kreutzberg GW, Thoenen H (1990) Ciliary neurotrophic factor prevents the degeneration of motor neurons after axotomy. Nature 345:440-441

265. Jiang Q, Yan Z, Feng J (2006) Neurotrophic factors stabilize microtubules and protect against rotenone toxicity on dopaminergic neurons. J Biol Chem 281:29391-29400

266. Aron L, Klein R (2011) Repairing the parkinsonian brain with neurotrophic factors. Trends Neurosci 34:88-100

267. Allen SJ, Watson JJ, Shoemark DK, Barua NU, Patel NK (2013) GDNF, NGF and BDNF as therapeutic options for neurodegeneration. Pharmacol Ther 138:155-175

268. Salvatore MF, Ai Y, Fischer B, Zhang AM, Grondin RC, Zhang Z, Gerhardt GA, Gash DM (2006) Point source concentration of GDNF may explain failure of phase II clinical trial. Exp Neurol 202:497-505

269. Bjorklund T, Kirik D (2009) Scientific rationale for the development of gene therapy strategies for Parkinson's disease. Biochim Biophys Acta 1792:703-713

270. Chen PS, Peng GS, Li G, Yang S, Wu X, Wang CC, Wilson B, Lu RB, Gean PW, Chuang DM, Hong JS (2006) Valproate protects dopaminergic neurons in midbrain neuron/glia cultures by stimulating the release of neurotrophic factors from astrocytes. Mol Psychiatry 11:1116-1125

271. Wu X, Chen PS, Dallas S, Wilson B, Block ML, Wang CC, Kinyamu H, Lu N, Gao X, Leng Y, Chuang DM, Zhang W, Lu RB, Hong JS (2008) Histone deacetylase inhibitors up-regulate astrocyte GDNF and BDNF gene transcription and protect dopaminergic neurons. Int J Neuropsychopharmacol 11:1123-1134

272. Nusse R, Varmus H (2012) Three decades of Wnts: a personal perspective on how a scientific field developed. EMBO $\mathrm{J}$ 31:2670-2684

273. Salinas PC (2007) Modulation of the microtubule cytoskeleton: a role for a divergent canonical Wnt pathway. Trends Cell Biol $17: 333-342$
274. Arenas E (2014) Wnt signaling in midbrain dopaminergic neuron development and regenerative medicine for Parkinson's disease. J Mol Cell Biol 6:42-53

275. Oliva CA, Vargas JY, Inestrosa NC (2013) Wnt signaling: role in LTP, neural networks and memory. Ageing Res Rev 12:786-800

276. Ciani L, Salinas PC (2005) WNTs in the vertebrate nervous system: from patterning to neuronal connectivity. Nat Rev Neurosci 6:351-362

277. Fanara P, Husted KH, Selle K, Wong PY, Banerjee J, Brandt R, Hellerstein MK (2010) Changes in microtubule turnover accompany synaptic plasticity and memory formation in response to contextual fear conditioning in mice. Neuroscience 168:167-178

278. Schlessinger K, McManus EJ, Hall A (2007) Cdc42 and noncanonical Wnt signal transduction pathways cooperate to promote cell polarity. J Cell Biol 178:355-361

279. Etienne-Manneville S, Hall A (2003) Cdc42 regulates GSK3 beta and adenomatous polyposis coli to control cell polarity. Nature 421:753-756

280. Etienne-Manneville S, Manneville JB, Nicholls S, Ferenczi MA, Hall A (2005) Cdc42 and Par6-PKCzeta regulate the spatially localized association of Dlg1 and APC to control cell polarization. J Cell Biol 170:895-901

281. Chen HJ, Lin CM, Lin CS, Perez-Olle R, Leung CL, Liem RK (2006) The role of microtubule actin cross-linking factor 1 (MACF1) in the Wnt signaling pathway. Genes Dev 20:1933-1945

282. Rawal N, Corti O, Sacchetti P, Ardilla-Osorio H, Sehat B, Brice A, Arenas E (2009) Parkin protects dopaminergic neurons from excessive Wnt/beta-catenin signaling. Biochem Biophys Res Commun 388:473-478

283. Anichtchik O, Diekmann H, Fleming A, Roach A, Goldsmith P, Rubinsztein DC (2008) Loss of PINK1 function affects development and results in neurodegeneration in zebrafish. J Neurosci 28:8199-8207

284. Berwick DC, Harvey K (2012) LRRK2 functions as a Wnt signaling scaffold, bridging cytosolic proteins and membranelocalized LRP6. Hum Mol Genet 21:4966-4979

285. Parisiadou L, Cai H (2010) LRRK2 function on actin and microtubule dynamics in Parkinson disease. Commun Integr Biol 3:396-400

286. Harvey K, Marchetti B (2014) Regulating Wnt signaling: a strategy to prevent neurodegeneration and induce regeneration. J Mol Cell Biol 6:1-2

287. Vale RD, Malik F, Brown D (1992) Directional instability of microtubule transport in the presence of kinesin and dynein, two opposite polarity motor proteins. J Cell Biol 119:1589-1596 